\title{
SPIDERS (ARANEAE) OF SUBOTICA SANDLAND (SERBIA): ADDITIONAL ARGUMENTS IN ENVIRONMENTAL PROTECTION
}

\author{
Gordana Grbić ${ }^{1}$, Ambros HängGi ${ }^{2}$ and Slobodan Krnjajić 3 \\ ${ }^{1}$ Educons University, Faculty of Environmental Protection \\ Vojvode Putnika 86, Sremska Kamenica, Serbia \\ E-mail: gordana.grbic.ns@gmail.com, https://orcid.org/0000-0002-7508-5614 \\ ${ }^{2}$ Naturhistorisches Museum Basel, Augustinergasse 2, CH-4001 Basel, Switzerland \\ E-mail:ambros.haenggi@bs.ch, https://orcid.org/0000-0002-2799-4282 \\ ${ }^{3}$ Institute for Multidisciplinary Research, Kneza Višeslava 1, Belgrade, Serbia \\ E-mail: titanus_serbia@yahoo.com,https://orcid.org/0000-0001-5278-4589
}

Good environmental management needs evidence-based conservation measures, and those measures need both faunistical and ecological information. Following this path, for the first time in Serbia, a faunistical research of spiders at Subotica Sandland was organised in 2014 as a base for ecological arguments in landscape management of the area. The spiders were collected at ten different habitats on sandy soil, in the period from 27th April till 30th October by pitfall trapping and sweep netting. A total of 16304 adult and 7246 juvenile individuals were captured, and 225 species from 27 families were determined. Thirty species represent new records for Serbia. Diversity and species compositions provided an insight into the quality of the habitats and the influence of the conservation and development measures that were already applied. The main endangerment factors are outlined. Conclusions and suggestions according to the analysis of the spider fauna, are mostly in correlation with those made earlier based on other groups of organisms. Within the scope of nature protection, wet and sandy meadows are prioritised over the woods. For future monitoring, two flagship and umbrella species are suggested: Argiope lobata (Pallas, 1772) for the sandy area and Dolomedes plantarius (Clerck, 1757) for the wetlands.

Keywords: Araneae, spiders, environmental protection, bioindicators, clear-cutting, mowing, nature protection, new records.

\section{INTRODUCTION}

The oldest written document about spiders in Serbia is on the species Geolycosa vultuosa (C. L. Koch, 1838) found near Belgrade (Spasojević 1891). Subsequent records correspond to several countries and territories that Serbia as a state implied over the years (Spasojević 1891, Chyzer \& Kulczyński 1894, 1897, Bresjančeva 1907, Stojićević 1929, Nikolić \& Polenec 1981, Deltshev et al. 2003) and they are sometimes difficult to track. Finally, available data were summarised by Deltshev et al. (2003), and the list contains 618 spider species from 36 families.

Between 2003 and 2019, additional papers appeared concerning the hypogeic (Ćurčić et al. 2007, Deltshev \& Ćurčić 2011, Deltshev et al. 2014) and the epigeic fauna (Ćurčić et al. 2007, Komnenov \& PavićEvić 2008, Stanković 
2010, 2012, Dudić et al. 2013). Some localities, like the Fruska Gora National Park (Tomić \& Grbić 2008, Grbić \& Savić 2010, Grbić et al. 2015), The Special Nature Reserve Zasavica (Grbić et al. 2011, Gajıć \& Grbić 2016) and Deliblato Sand (Grbić et al. 2019) were more systematically researched. The study of the Vršac Mountain also began (GAJIć, in litt.). However, many more protected and unprotected areas are still left unexplored. One of those areas was Subotica Sandland in the northern part of Serbia.

A landscape of outstanding features, the Subotica Sandland ("OfFicial GaZetTe of RS" no. 66/91, 127/2003, 113/2004), occupies the southern part of the Danube-Tisza Interfluve Area (Fig. 1) in Serbia. The northern part of this area, the Kiskunság National Park, is situated in Hungary and spreads northwards to Budapest.

Unlike the flora, the fauna of the Subotica Sandland has not been studied thoroughly (INPs 2003). Most of the information is about birds and plants, so arguments for nature protection management are based on that knowledge. No information on spiders and very little on other small, ground-living invertebrates is available (INPs 2003). So, the question arises: could the management be based on small ground-living invertebrates like spiders and be beneficial for them, too?

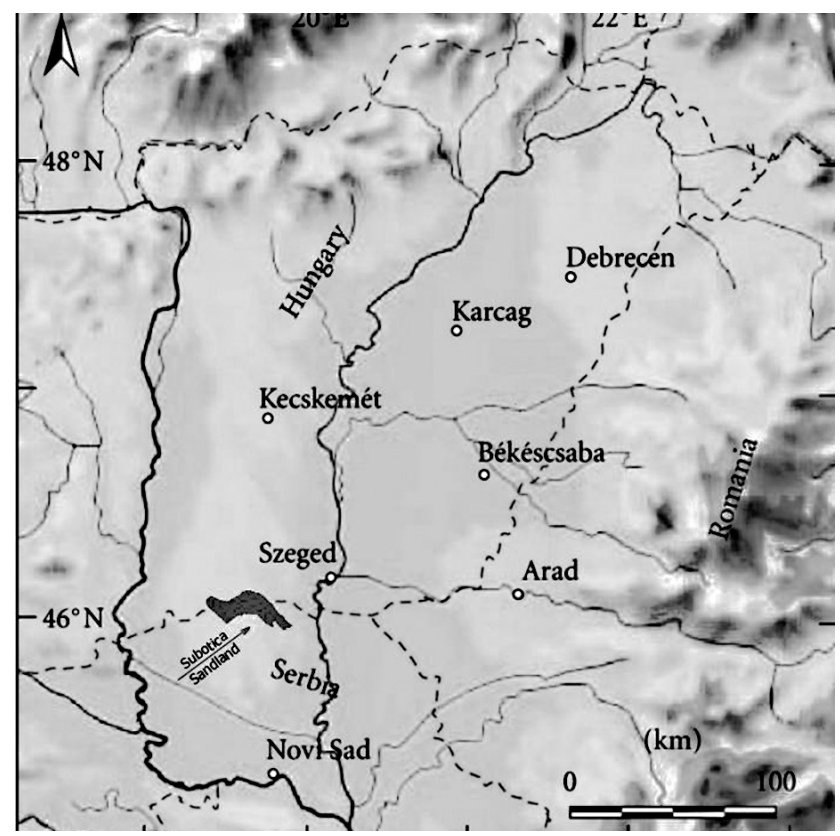

Fig. 1. Geographical position of the Subotica Sandland (Serbia) at the southern part of the Danube-Tisza Interfluve (area marked in black with arrow pointer). The northern part belongs to the Kiskunság Sand which spreads northwards to Budapest. The Serbian - Hungarian border separates both protected areas 
Spiders could be influenced by complexes of abiotic and biotic factors that govern the area they inhabit (Foelix 1996). For these reasons, in some European countries spiders are used as ecological indicators in nature conservation (Clausen 1986, Neet 1996, Maelfait \& Hendrichx 1998, Pozzi et al. 1998, Blick 1999, Maelfait et al. 2003). There is a link between changes in habitat quality and changes in the composition of the spider community and viceversa - a visible change in the specific community structure of the spiders can indicate changes in the quality of habitat (Maelfait \& Hendrichx 1998, Maelfait et al. 2003). Also, in some cases, based on the presence or absence of highly specialised species in a particular habitat, conclusions can be drawn concerning the quality of the studied habitat e.g. the degree of disturbance or impacts of protection measures (Maelfait \& Hendrichx 1998, Maelfait et al. 2003, Pozzi \& Borcard 2001, Szmatona-Turi \& Vona-Turi 2016).

Furthermore, some spider species are used as charismatic flagship species, to raise public awareness for conservation measures (MiLAsowszky \& Zulka 1998, Fukushima et al. 2019). Even if a flagship species has been defined in various ways (CARo et al. 2004), the general idea is to make it a symbol and leading element of an entire ecosystem conservation campaign (CARo et al. 2004, Sattler et al. 2013). Very often flagship species are also thought to be umbrella species that depend on key environmental elements in an ecosystem, and so stand in for the needs of other species. Flagship species mostly are big, beautiful and well-known species. In the case of spiders, flagship species include Brachypelma species in America (Fuкushima et al. 2019), and the giant European wolf spider Lycosa singoriensis (Laxmann, 1770) in the National Park Neusiedler See-Seewinkel (Milasowszky \& ZulKa 1998).

With the idea to test the assumptions above, a project was organised in the Nature Protection zone of Subotica Sandland. The main goal of it was to provide faunistic and ecological information about spiders and to suggest evidencebased conservation measures. It was designed to create a link between spiders as bioindicators, habitat quality and maintenance activities realised within the area

Several starting assumptions and hypotheses were established: 1) the inventory list of species will contribute not only to Subotica Sandland but to the general knowledge of Serbian arachnofauna; 2) as spiders are good bioindicators of the environment, they could be useful as an additional argument for nature conservation in Subotica Sandland; 3) as diversity and species compositions can give us an insight into the environmental quality of the studied habitats, conclusions about the influence of the active conservation and development measures at the different localities can be drawn; 4) these conclusions will be comparable with those based on other groups of organisms (plants or birds) and will help to evaluate the existing protection management. Last but not least, some highly specialised species could be found and suggested as indicator, flagship, and/or umbrella species for a future monitoring program. 


\section{MATERIAL AND METHODS}

\section{Study area}

The protected area of Subotica Sandland covers some 2500 ha and is composed of widely distributed sandy dunes covered by steppe, meadows, sandy and marsh plant vegetation, with the highest peak at $134 \mathrm{~m}$ a.s.l. (INPs 2003). The dune area is dry, but interdune depressions are influenced by groundwater close to the surface, creating marsh and wet soils. In larger depressions there are bogs. The only river flowing through the Subotica Sandland is the Körös River, which is slowly drying out (INPs 2003). Nowadays, open sands are very rare. Autochthonous and planted forest fragments intersect the whole area. A large part is under orchards and vineyards on sand (INPs 2003).

According to regulations on the conservation of The Subotica Sandland ("OfFicial GAZETTE of RS", no. 66/91, 127/2003, 113/2004), three levels of the protection regime are established in the area, to preserve the natural and semi-natural conditions - Level I: Total protection (8.32\% of the area); Level II: Active protection (21.55\% of the area); Level III: Proactive protection $(69.72 \%$ of the area).

Level I: covers the most vulnerable areas like lowland peat meadows and other wet fields, plus some fragments of original sandy and steppe meadows. The only activities that are permitted here are scientific research or monitoring and some measures related to the conservation and enhancement of natural species within a particular plan and program (clear-cutting, mowing, grazing).

Level II: preserves meadows, pastures and neglected land with typical sandy vegetation. A significant part encompasses planted and autochthonous wood fragments. There are also microhabitats of some relict or endemic species that are isolated and enjoy level I protection. Special measures are undertaken to improve and preserve indigenous natural resources. Controlled educational excursions and eco-tourism are also permitted.

Level III: is a forest area with some agricultural land. Only $9 \%$ of the forest consists of fragments of autochthonous white and grey poplar or oak wood, whilst $91 \%$ is planted wood of black locust, common hackberry or black pine. Here also exist microhabitats of some relict or endemic species that are isolated and enjoy level I protection. In this area development and economic use are allowed within ecologically sustainable limits.

In our research, three localities with ten different habitats were investigated in 2014 (Fig. 2). All selected study sites are in level I or II protection regime with specific active conservation and development programs. The selection of the habitats in the terrain was made together with the rangers of the protected area. Description of the study sites was based on INPs (2003) and the reports of the ranger service of the Public company "PalicLudas" that manage the area. Geographical coordinates were given as WGS84 in degrees with decimal minutes.

\section{Characteristics of study sites}

Locality 1. Local name: Krčevine; N460․ $545^{\prime}$ E19² $43.254^{\prime}$, five habitats.

M1: sandy meadow, dominated by the xerophilic steppe vegetation on brown sand, plant community Chrysopogonetum pannonicum Stjepanović-Veseličić 1953, 127 m a.s.l., shadow at ground $0 \%$, vegetation cover $20-30 \%$, litter $10 \%$, the floor is not fully covered, there are places with visible sand, the visible hawthorn shrubs, roses and black locust are cut as a regular revitalisation work of autochthonous sandy meadow. N46 $09.545^{\prime}$ E19 $43.254^{\prime}$. 
W1: fragment of autochthonous poplar wood (Populus alba), very young wood (around 30 years) with poorly developed shrub layer, natural not planted, $126 \mathrm{~m}$ a.s.l., shadow at ground $60 \%$, vegetation cover $10 \%$, litter $20 \%$. N46 $09.482^{\prime}$ E19 $43.279^{\prime}$.

W2: fragment of mixed poplar wood (Populus alba + Populus nigra), also autochthonous and very young wood (30 years old) with a well-developed shrub layer, $125 \mathrm{~m}$ a.s.l., shadow at ground $40 \%$, vegetation cover $30 \%$, litter $80 \%$. N46 $09.521^{\prime}$ E $19^{\circ} 43.339^{\prime}$.

W3: fragment of mixed poplar and oak wood (Quercus robur + Populus alba), autochthonous, slightly inclined, $120 \mathrm{~m}$ a.s.l., shadow at ground $90 \%$, vegetation cover $10 \%$, litter

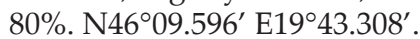

W4: self-grown grove of black locust (Robinia pseudoacacia), slightly inclined, $126 \mathrm{~m}$ a.s.l., shadow at ground $60 \%$, vegetation cover $10 \%$, litter $0 \%$. N46 $09.537^{\prime}$ E $19^{\circ} 43.232^{\prime}$.

All these habitats are in Level II of the protection regime. This is an area of active protection with a precise conservation and development program, all to preserve the indigenous sandy steppe vegetation at habitat M1. Such activities began in 2008. The clearcutting was done two or three times a year, which depends on the season. Usually, the first cutting of older Robinia and hawthorn trees is organised in December of the current year, while the following year, tree sprouts are cut twice (the second half of July and November). In 2014, cutting shoots were organised in late July and late November.

Locality 2. Local name: Livada kod Djavolovog kanala, N4609.703’ E1944.008'; three habitats.

M2: meadow, plant community Festucetum vaginate danubiale Soó 1929, mown twice a year, high influence of groundwater, $122 \mathrm{~m}$ a.s.l., shadow at ground $0 \%$, vegetation cover

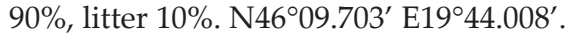

W5: flooded wood of white and grey poplar (Populus alba + Populus canascens) where a high groundwater level reaches up to a height of $1 \mathrm{~m}$. The bark is covered with moss, 120

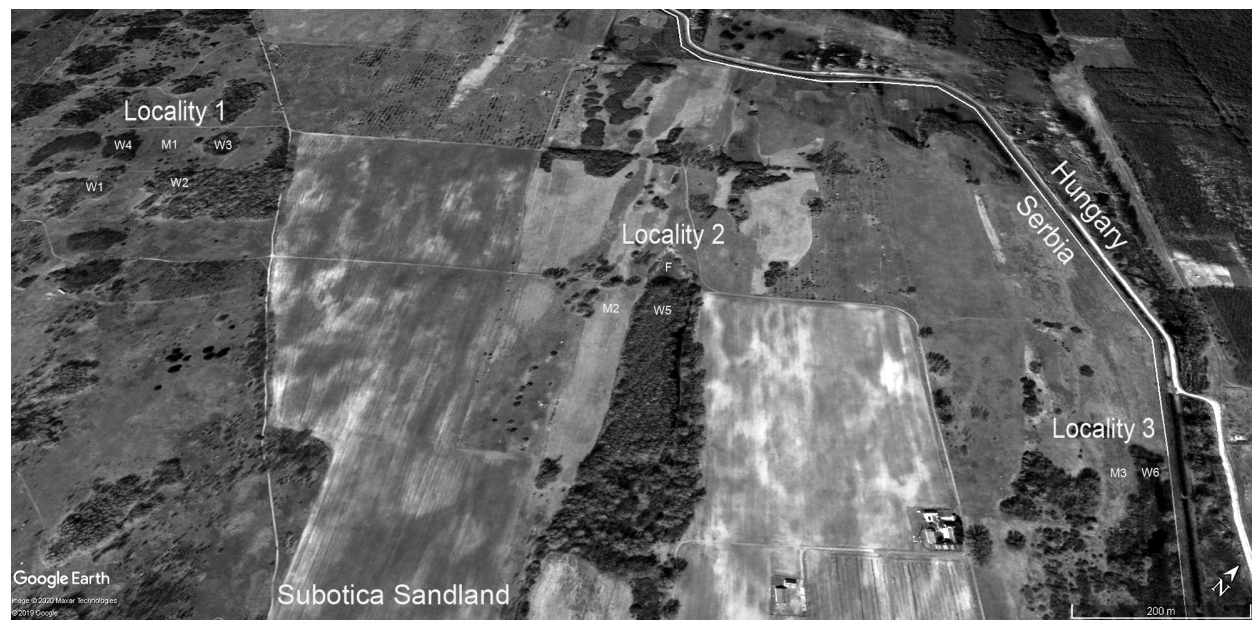

Fig. 2. Position of the localities at Subotica Sandland (Serbia) in 2014; Locality 1: Krčevine, Locality 2: Livada kod Djavolovog Kanala, Locality 3: Livada kod Stare škole. Habitats: M1 (Chrysopogonetum pannonicum), W1 (Populus alba), W2 (P. alba + P. nigra), W3 (Quercus robur + P. alba), W4 (Robinia pseudoacacia), M2 (Festucetum vaginate danubiale), W5 (P. alba + P. canascens), F (Carex spp.), M3 (Molinietum caeruleae), W6 (Celtis ocidentalis) 
m a.s.l. shadow at ground $70 \%$, vegetation cover $10 \%$ (+20\% moss), litter $10 \%$. N46 $09.696^{\prime}$ E194․ $978^{\prime}$.

F: a wet field of sedges, Carex spp., high influence of groundwater, in some years level of water on the field can be $20 \mathrm{~cm}$ for several days, and the activity of wild boars is common, $119 \mathrm{~m}$ a.s.l. shadow at ground $0 \%$, vegetation cover $0-80 \%$, litter $0 \%$. N46 $09.742^{\prime}$ E19 $43.969^{\prime}$.

Locality 3. Local name: Livada kod stare škole, N460․ $099^{\prime} \mathrm{E} 19^{\circ} 44.489^{\prime}$; two habitats.

M3: lowland peat meadows along the border to Hungary and the Körös River, the dominant plant association is Molinietum caeruleae (All 1922) W. Koch 1926 s.l., usually mown twice a year, flooded by groundwater. Level of water can reach $20 \mathrm{~cm}$ and can stay for several weeks, $117 \mathrm{~m}$ a.s.l., shadow at ground $0 \%$, vegetation cover $100 \%$, litter $0 \%$.

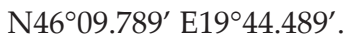

W6: fragment of common hackberry (Celtis ocidentalis) and willow (Salix caprea), a small shrubby place around the lowland peat bog, that has water all year, but levels vary, situated beside the Körös River and Hungarian border, $115 \mathrm{~m}$ a.s.l., shadow at ground $80 \%$, vegetation cover $20 \%$, litter $10 \%$, general appearance shrubby rather than woody. $\mathrm{N} 46^{\circ} 09.776^{\prime} \mathrm{E}^{\circ} 9^{\circ} 44.520^{\prime}$.

All habitats in Locality 2 and 3 are in Level I of the protection regime. There is a strict management plan for the meadows M2 and M3. At the meadows M2 and M3, mowing was organised twice a year, and the corridors left behind as re-colonisation sites are about $50 \mathrm{~cm}$ wide. In 2014, the first mowing in the M3 meadow was at the end of June, whilst in the M2 meadow it was in early July. The second mowing in both meadows was organised in the second half of September. Apart from these management measures, only scientific research is allowed.

\section{Collecting protocol}

Spiders were collected with pitfall traps and sweep netting. Pitfall traps were made of plastic cups with a volume of $50 \mathrm{cl}$ and an opening diameter of $70 \mathrm{~mm}$, with a roof of
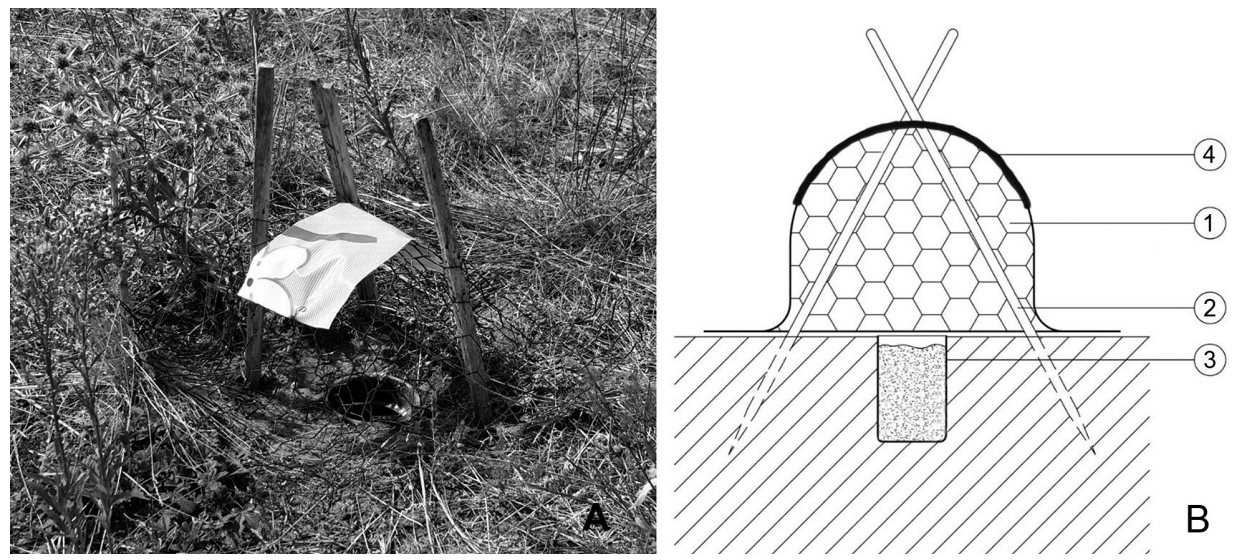

Fig. 3. Pitfall traps used at Subotica Sandland in 2014. A) in situ at habitat M1, Locality 1. B) Construction of the traps 1) wire mesh, 2) wooden sticks, 3) sampling cup, 4) plastic folium as roof 
wire mesh and a plastic folium (Fig. 3). Wooden sticks were used to fix the wire mesh to the ground. Trapping liquid was $40 \mathrm{cl}$ of formalin (4\%) with a few drops of detergent. In total, 60 traps were placed, 6 traps per habitat were positioned in a line, with $10 \mathrm{~m}$ distance between each trap. The sampling period lasted from 27th April till 30th October 2014 and the traps were emptied on a frequency of 15 days. Sweep netting was applied with no standardised procedure, only at habitats M1, M2, and M3, in order to complete the species list.

\section{Spider determination}

Determination of species was primarily based on the website Araneae - spiders of Europe (Nentwig et al. 2020). Further literature for individual groups or species was also used but will be mentioned only, where details are discussed. Reference collections are deposited in the Natural History Museum of Basel, Switzerland, in the Natural History Museum, Belgrade, Serbia, and in the Grbić private collection. Nomenclature follows The World Spider Catalogue (Wsc 2020).

The species that were identified as "new to Serbia" were singled out as a separate chapter in results. Their global distribution is simplified according to WsC (2020) (for Europe see Nentwig et al. 2020) and the literature cited for determination. Information about the ecological niches of the species is given as "habitats" and preferences are mostly based on Nentwig et al. (2020) and HäNGGi et al. (1995); otherwise, literature is cited. The listing is in alphabetical order by family and species names. Most of these species were not caught in high numbers; we, therefore, list all material with dates. If useful, taxonomical notes, often with photos of the habitus and genital structures, are given. Photos were made with a KEXENCE 6000 with autostaking.

The analysis of the Red lists of several countries in Europe (GAjdoš \& Svanton 1993, ŘezÁč et al. 2015, BLICK et al. 2016, HARVEy et al. 2017, HyväRINEN et al. 2019), is presented as additional information only for the "new species for Serbia", since there is no Red Book or Red List of spiders in Serbia.

\section{Data analysis}

The analysis of the spider fauna was done based on qualitative and quantitative methods. Qualitative methods involved the total number of spider species, as well as the presence or absence of specialists. Quantitative methods involved the relative or absolute presence of particular species or groups of species. To gain more information about species community, rareness and commonness of the species, we applied several indices of diversity and similarity: Simpson's Diversity Index (D), Shannon-Weaver's Diversity Index $\left(\mathrm{H}^{\prime}\right)$ and Shannon's Equality Index of Species (E). According to Magurran (2004), the most abundant species influence the value of Simpson's index, while the Shannon-Weaver index is more sensitive to the frequency of rare species. For a better presentation of the results, we calculated the complement value of Simpson's Diversity Index (1-D). Renkonen similarity indexes (RS) were used to test the specificity of the spider communities in the habitats. This index is based on the relative abundance of the species and is calculated according to the following formula: $\mathrm{RS}_{\mathrm{ij}}=\sum$ min $\mathrm{p}_{\mathrm{ni}} ; \mathrm{p}_{\mathrm{nj}}$, where $\mathrm{i}, \mathrm{j}=$ sample of habitat $\mathrm{i}$ and $\mathrm{j}, \mathrm{p}_{\mathrm{ni}} \mathrm{p}_{\mathrm{nj}}$ relative abundance of species $n$ in sample $i$ and $j$ respectively. For calculating the dendrogram UPGMA cluster analysis was used. 


\section{RESULTS}

\section{Faunistic overview}

In total, 16304 adult specimens (11239 males, 5065 females) and 7246 juveniles were caught, and 225 species from 27 families were identified. Only Eresus sp. was identified to the genus level, due to mismatches between diagnostic characters and material present. Altogether 196 species were caught using pitfall traps. Sweeping yielded 63 species, 29 of these were never caught by pitfalls. Only 34 species were caught by both methods. In Table 1, a short overview and some important faunistic data are given. A detailed species list with individuals per habitat is given in the Supplement.

The largest family in the study material was Linyphiidae with 47 species (20.8\%), followed by Gnaphosidae (27 sp., 12\%), Lycosidae (27 sp., 12\%), Thomisidae (22 sp., 9.7\%), Araneidae (18 sp., 8\%), Salticidae (17 sp., 7.5\%) and Theridiidae (13 sp., 5.7\%). All other families had less than 10 species. Five of them $(18.5 \%)$ were represented by only two species and eight families $(29.6 \%)$ by one. Pardosa alacris with 3182 individuals or 19.5\% (1770 $\delta$ ภ and 1412 우) was by far the most abundant species, followed by Ozyptila praticola (1612 in-

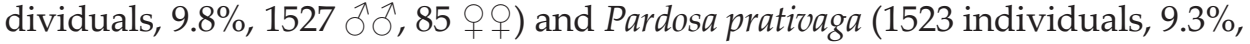

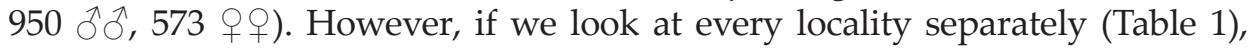
there is a clear difference between the most numerous families and species. This indicates differences in environmental conditions that are present at the sites.

Of the 225 spider species recorded in this area, 30 are new records for the Serbian arachnofauna (marked with an asterisk) in the Supplement. These species will be discussed below.

Table 1. An overview of the most important faunistic data on spiders collected in 2014 at three localities in the Subotica Sandland, Serbia.

\begin{tabular}{lcccc}
\hline & Subotica Sandland & Locality 1 & Locality 2 & Locality 3 \\
\hline Individuals & 16304 & $6515(40 \%)$ & $4801(29.4 \%)$ & $4988(30.6 \%)$ \\
Species & 225 & $115(51.1 \%)$ & $146(64.8 \%)$ & $138(61.3 \%)$ \\
Most species & Linyphiidae & Gnaphosidae & Linyphiidae & Linyphiidae \\
rich families & (47 species) & $(20$ species) & (35 species) & (31 species) \\
\hline \multirow{5}{*}{$\begin{array}{l}\text { Most } \\
\text { abundant } \\
\text { species }\end{array}$} & Pardosa alacris & Pardosa alacris & Pardosa prativaga & Pachygnatha degeeri \\
& Pardosa prativaga & Drassylus villicus & Piratula hygrophila & Trochosa hispanica \\
& Pachygnatha degeeri & Zelotes apricorum & Trachyzelotes pedestris & Arctosa lutetiana \\
\hline
\end{tabular}




\title{
Family Araneidae \\ Singa lucina (Audouin, 1826)
}

Material: 30.05.2014 M3 1․

Determination: LoKSA 1972, Levy 1984.

Global distribution: Mediterranean to Central Asia.

Habitat: Dense vegetation on the bank of fish ponds (Levy 1991).

Note: The species manly lives on low plants and is commonly collected by sweeping the vegetation, whilst their orb webs are hardly noticed (Levy 1984). It closely resembles specimens of Singa hamata and S. nitidula, and mixed collections of all three species are very common (Levy 1984). In accordance with literature data (LeVy 1984), our finding is also connected with water. According to Nentwig et al. (2020) Singa lucina is already known from most of the Balkan countries. Its female was figured by LoKSA (1972) from Hungary and by DRENSKY (1943) from Bulgaria. Singa lucina is not treated in any of the consulted Red List of species.

\section{Family Clubionidae \\ Clubiona rosserae Locket, 1953}

Material: 27.06.2014 F $1{ }^{\lambda}$.

Determination: Wiehle 1965, Roberts 1985, Dawson 2011.

Global distribution: Europe.

Habitat: Wet habitats (DAwson 2011).

Note: Clubiona rosserae seems to be a very rare species. Records are known from only seven European countries. According to Dawson (2011) the species was recorded at only two sites in England where it was occasionally found. Even intensive research at the locus typicus from 2002 to 2005 was not successful (DAwson 2011). On the Subotica Sandland, we found it in habitat F, a moist field of Carex spp. The single male was captured in June, which is in contrast to the literature data (males in October, according to Nentwig et al. 2020). This very rarely collected species is listed as vulnerable in England and endangered in Slovakia.

\author{
Family Dictynidae \\ Argenna patula (Simon, 1874)
}

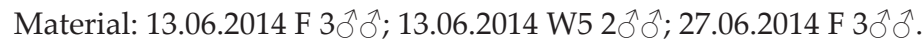

Determination: Locket \& Millidge 1951, Wiehle 1953, Roberts 1985.

Global distribution: Palaearctic.

Habitat: Under detritus (Nentwig et al. 2020). Under stones, often in dry habitats with scarce vegetation (Roberts 1985). Saline wetlands (halotolerant) (FINCH 2008).

Note: There are some problems for distinguishing the species from Argenna subnigra (O. pickard Cambridge, 1861) and, controlling museum collections, one will regularly find miss-matched determinations in the older times. In the males the form of the palpal tibia is a quite good character: short, rather square in subnigra and longer in patula (WIEHLE 1953). The conductor has no large bulb on the ventral side (KuZmin \& Esyunin 2016) and in A. subnigra there is a tuft of thick hair in the dorsal side of the tibia that is missing in A. patula (Fig. 4). The published information about the ecology of the species is somewhat confusing since it can be found from wet to dry habitats, mostly seashores (WIEHLE 1953, RoBERTs 1985, FINCH 
2008). In our study, we found it in the very wet (groundwater) field of Carex spp. (habitat F). An important environmental factor for the species could be the sandy soil rather than the saline impact (WIEHLE 1953). The species is critically endangered in the Czech Republic, vulnerable in Slovakia, near threatened in Finland and least concern in Sweden.

\section{Lathys stigmatisata (Menge, 1869)}

Material: 13.06.2014 M1 2우.

Determination: Marusik et al. 2015, Wiehle 1953, Roberts 1998, (sub Lathys puta).

Global distribution: Europe, Turkey.

Habitat: In sunny localities, on the ground and on lichens.

Note: This xerothermophilic species was to be expected for Serbia even if not yet known from the neighbouring countries to the west and east (Nentwig et al. 2020). The habitat of our finding (sandy meadow M1) fits well to the ecological requirements of the species as known from the literature. It is listed as vulnerable (England, Czech Republic) in the Red List of species.

\section{Family Gnaphosidae Berlandina cinerea (Menge, 1872)}

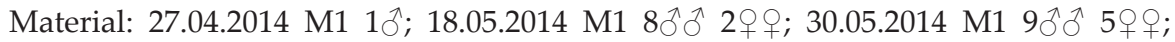

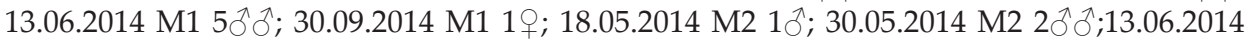

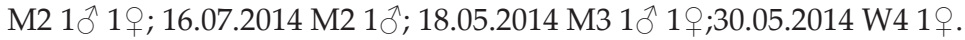

Determination: Grimm 1985, Tuneva \& Esyunin 2002, Miller 1971.

Global distribution: Palearctic.

Habitat: In dry, sandy locations under lichens or heath.

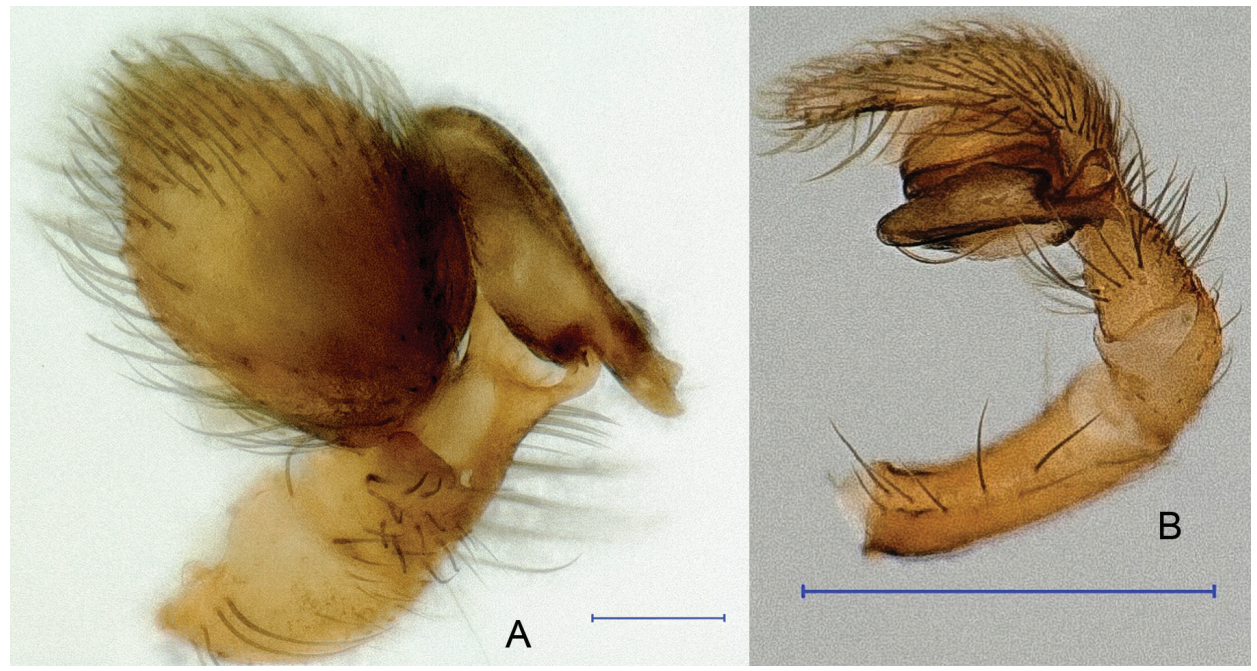

Fig. 4. Argenna patula, male palp: A = conductor of the right, expanded palp, B = left palp, retrolateral. Scale bars: $0.1 \mathrm{~mm}$ for A, $0.5 \mathrm{~mm}$ for B 


\section{Gnaphosa mongolica Simon, 1895}

Material: 30.05.2014 M1 2ðð1; 27.06.2014 M1 1ð.

Determination: Weiss \& Marcu 1988, Ovtsharenko et al. 1992, Szita et al. 2005.

Global distribution: Palearctic (not in Western Europe).

Habitat: Under stones in the steppe

Note: The determination of this species is not entirely clear. Our material fits quite well to the figures of Weiss \& MArcu (1988, sub Gnaphosa spinosa Kulczyński, 1897), but less to the figures in the other cited literature. The base of the median apophysis looks somewhat like the one of Gnaphosa muscorum (L. Koch, 1866), but the median apophysis seems to be a little bit expanded (Fig. 5). The tibial apophysis is smoothly bent without an inclined tip as in WeIss and MARCU (1988) and not with a median thickening as in SzITA et
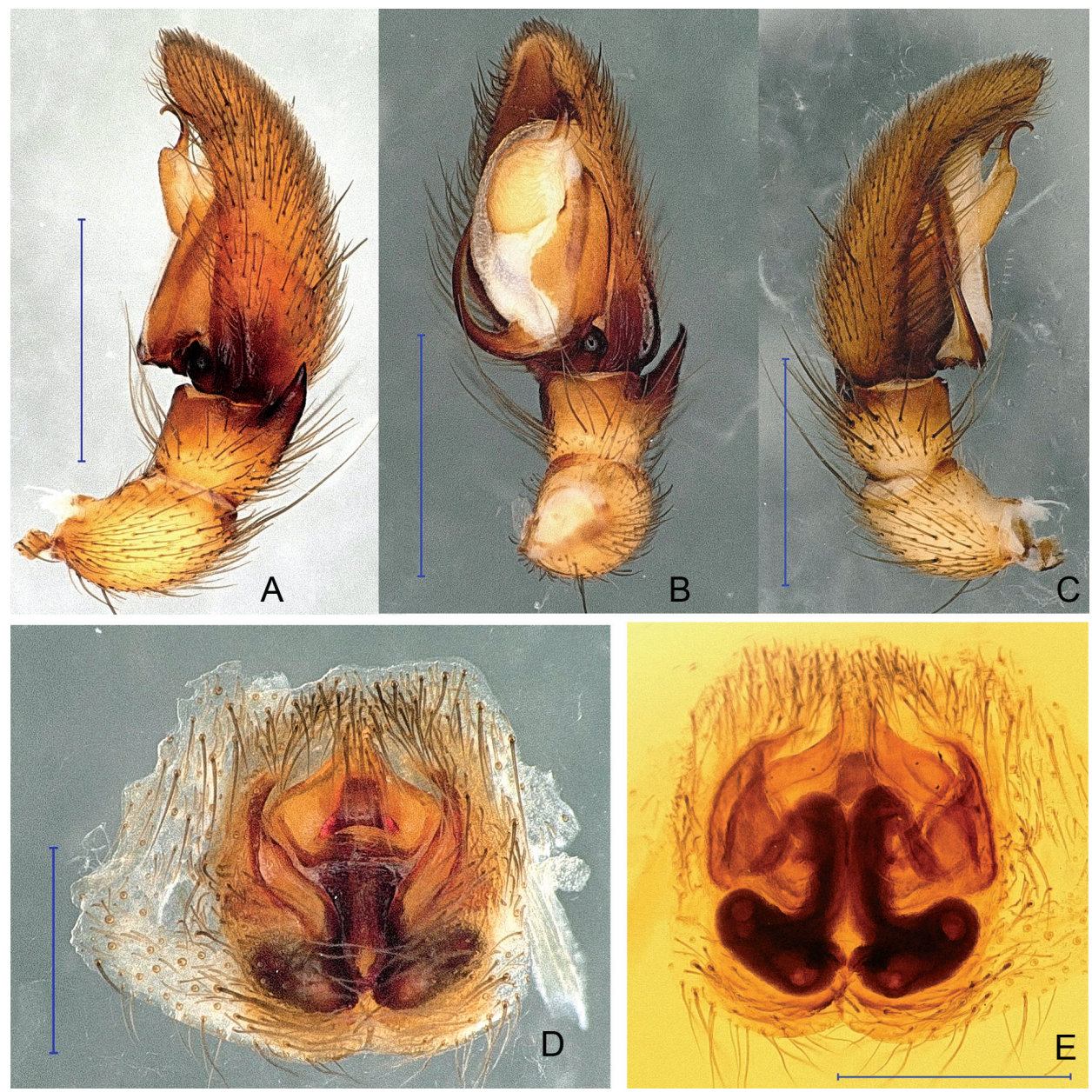

Fig. 5. Gnaphosa mongolica, $\mathrm{A}-\mathrm{C}=$ male left palp, $\mathrm{A}=$ retrolateral, $\mathrm{B}=$ ventral, $\mathrm{C}=$ prolateral, $\mathrm{D}=$ epigyne, ventral, $\mathrm{E}=$ vulva, dorsal. Scale bars: $1 \mathrm{~mm}$ for $\mathrm{A}-\mathrm{C}, 0.5 \mathrm{~mm}$ for $\mathrm{D}-\mathrm{E}$ 
al. (2005) or Ovtsharenko et al. (1992). Concerning the female, we think that the figures in Weiss and MARCU (1988) also correspond better to our material than those in Ovtsharenko et al. (1992) and Szita et al. (2005). Gnaphosa spinosa was synonymised with G. mongolica by Ovtsharenko et al. (1992). At the moment, and without more material, we are not able to decide whether the small differences represent different species or even a new species.

In Hungary, the species is known since the late 19th century (sub Gnaphosa spinosa) and inhabits sandy meadows (Szita et al. 2005). In the Subotica Sandland it was also found in the similar sandy habitat (habitat M1) with dominant xerophilous steppe vegetation on brown sand. To our knowledge, no photos of the genital structures are available, so we added some (Fig. 5) to facilitate determination in future. In the countries where the species is present no Red List of species exists. The species may be very abundant in suitable habitats (SziTa et al. 2005). However, with the limited geographical distribution in Europe and the narrow ecological niche (sandy steppe, a habitat type under economic pressure) we think that it should be classified as an endangered species.

\section{Haplodrassus bohemicus Miller et Buchar, 1977}

Material: 30.05.2014 M1 3ðð1우 16.08.2014 M2 1ㅇ․

Determination: Miller \& Buchar 1977, Kovblyuk et al. 2012, Bosmans et al. 2018.

Global distribution: Southern and Eastern Europe (Bosmans et al. 2018).

Habitat: Meadows, steppes and sand dunes (Kovblyuk et al. 2012).

Note: This species was described based on specimens from steppes of Bohemia in the Czech Republic (Miller \& Buchar 1977). In the review on the Mediterranean Haplodrassus Bosmans et al. (2018) questioned the identity of the specimens from Ukraine (Kovblyuk et al. 2012) because of minor differences in the figures of the different authors. Our material (Fig. 6) corresponds well to the figures of the original description (Miller \& Buchar 1977) and the photos of Bosmans et al. (2018). Current records are mainly from a sandy meadow (habitat M1) which is dominated by the xerophilic steppe vegetation on brown sand. However, one + was caught in the meadow (M2). Moreover, it was caught quite late in the year (August) compared to reports in the literature (June). The species is classified as critically endangered in the Czech Republic.

\section{Haplodrassus moderatus (Kulczyński, 1897)}

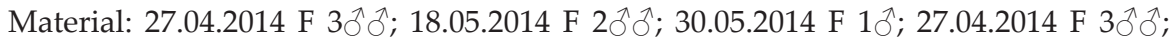

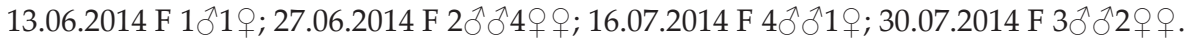

Determination: Miller (1971), Grimm (1985), Marusik \& Logunov (1995).

Global distribution: Palaearctic.

Habitat: In humid meadows, moors and bog forests.

Note: Rarely found species (Nentwig et al. 2020); however, this could be the result of a low number of investigations in swampy areas. The species is missing in the Mediterranean region and Serbia together with Romania seem to be the southernmost countries with records of the species. We add some photos of the male palp and the epigyne (Fig. 7). All our captures (27 individuals) come from the very wet Carex spp. field (habitat F). Haplodrassus moderatus is classified as endangered in Slovakia and the Czech Republic, but not endangered in Sweden and Germany. 


\section{Family Lycosidae \\ Pardosa maisa Hippa et Mannila, 1982}

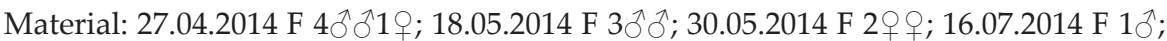
27.04.2014 M2 1ð.

Determination: Hippa \& Mannila (1982), Szinetár \& Guitprecht (2001), Gajdoš et al. (2019).

Global distribution: Palaearctic (without western Europe).

Habitat: In very wet habitats such as the sphagnum layer of moors and fens.

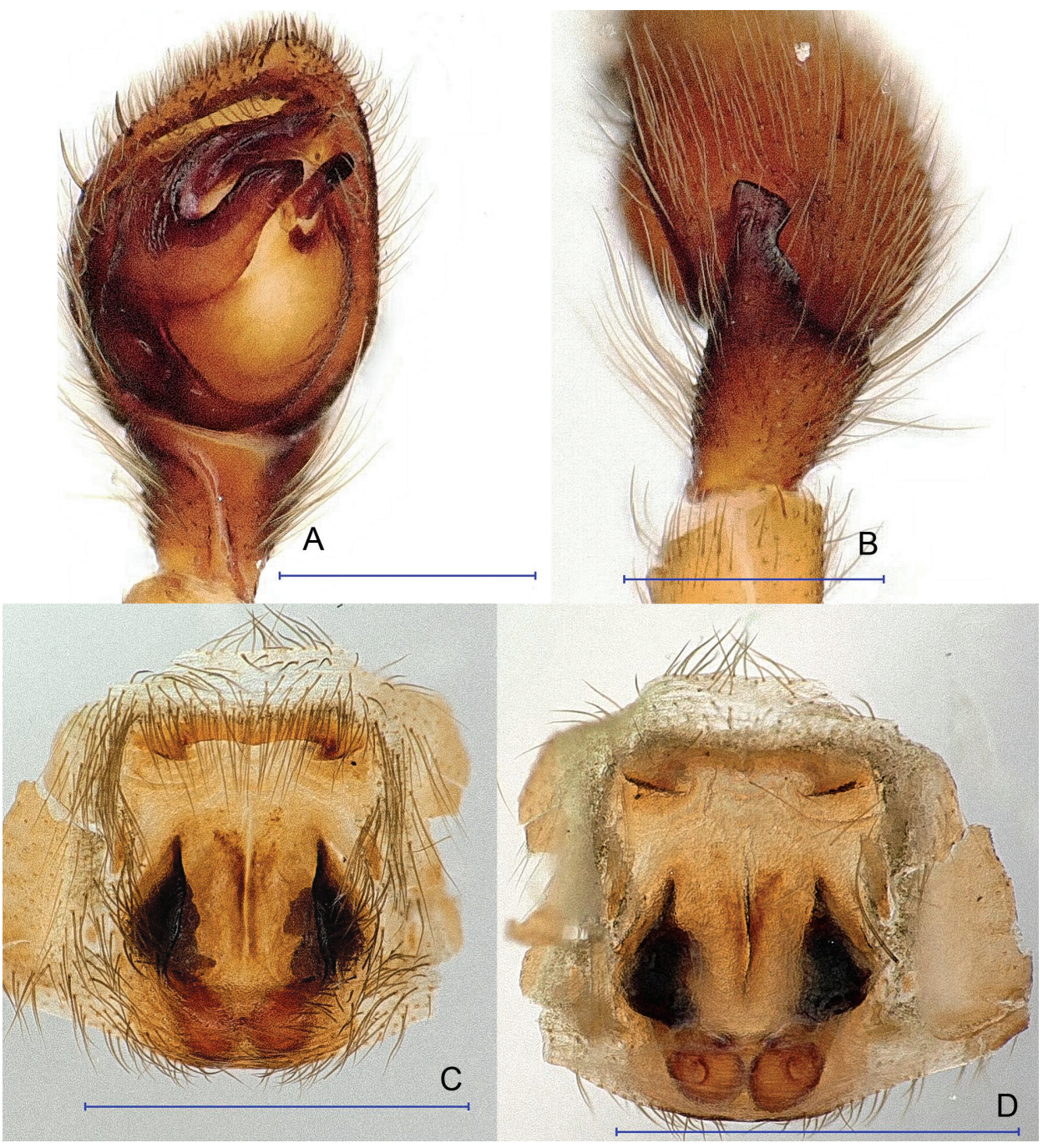

Fig. 6. Haplodrassus bohemicus: $\mathrm{A}-\mathrm{B}=$ male left palp, $\mathrm{A}=$ ventral, $\mathrm{B}=$ tibial apophysis, $\mathrm{C}-\mathrm{D}=$ epigyne in clove oil, $\mathrm{C}=$ ventral, $\mathrm{D}=$ dorsal. Scale bars: $0.5 \mathrm{~mm}$ for $\mathrm{A}-\mathrm{B}, 1 \mathrm{~mm}$ for $\mathrm{C}-\mathrm{D}$ 
Note: This species was originally described from the transition zone between a pine peat bog and a swamp with acidophilous Sphagnum mosses (Hippa \& ManNiLA 1982). In Hungary, it was found in fen meadows with good water supply (SzINETÁr \& GUITPRECHT 2001). In our material, Pardosa maisa was recorded in a wet field of sedges (habitat F) and with a single $\delta$ in the nearby meadow (habitat M2). The known worldwide distribution, as mentioned above is not continuous. The reason for this is unknown. It could be a result of the natural distribution of the spider or because of low research intensity in wet habitats. The locality in Serbia is the southwestern border of its distribution. In our specimens, in contrast to Nentwig et al. (2020) the lateral bands on the prosoma are clearly visible (Fig. 8) as also shown in Gajdoš et al. (2019). In the Czech Republic, the species is classified as critically endangered and in Finland as nearly threatened.
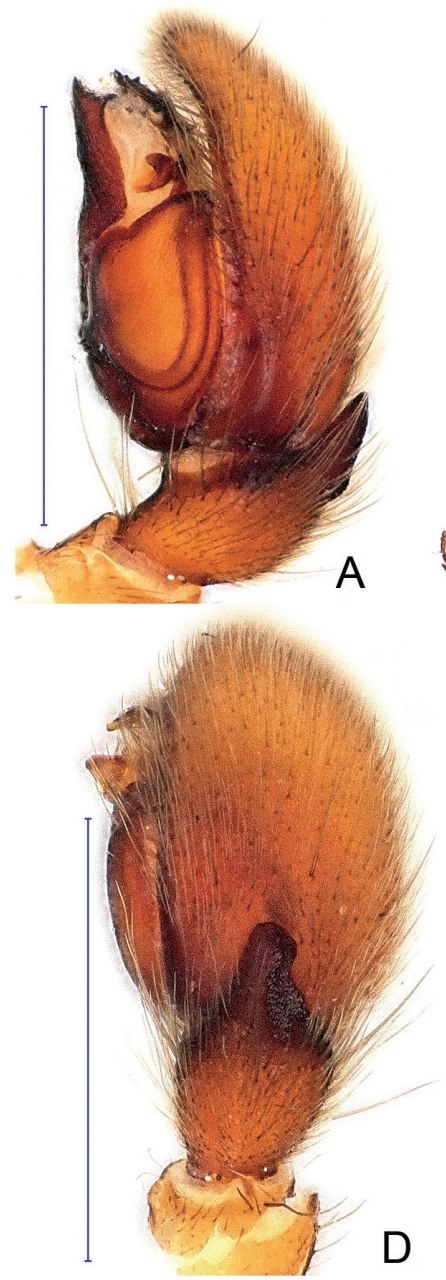
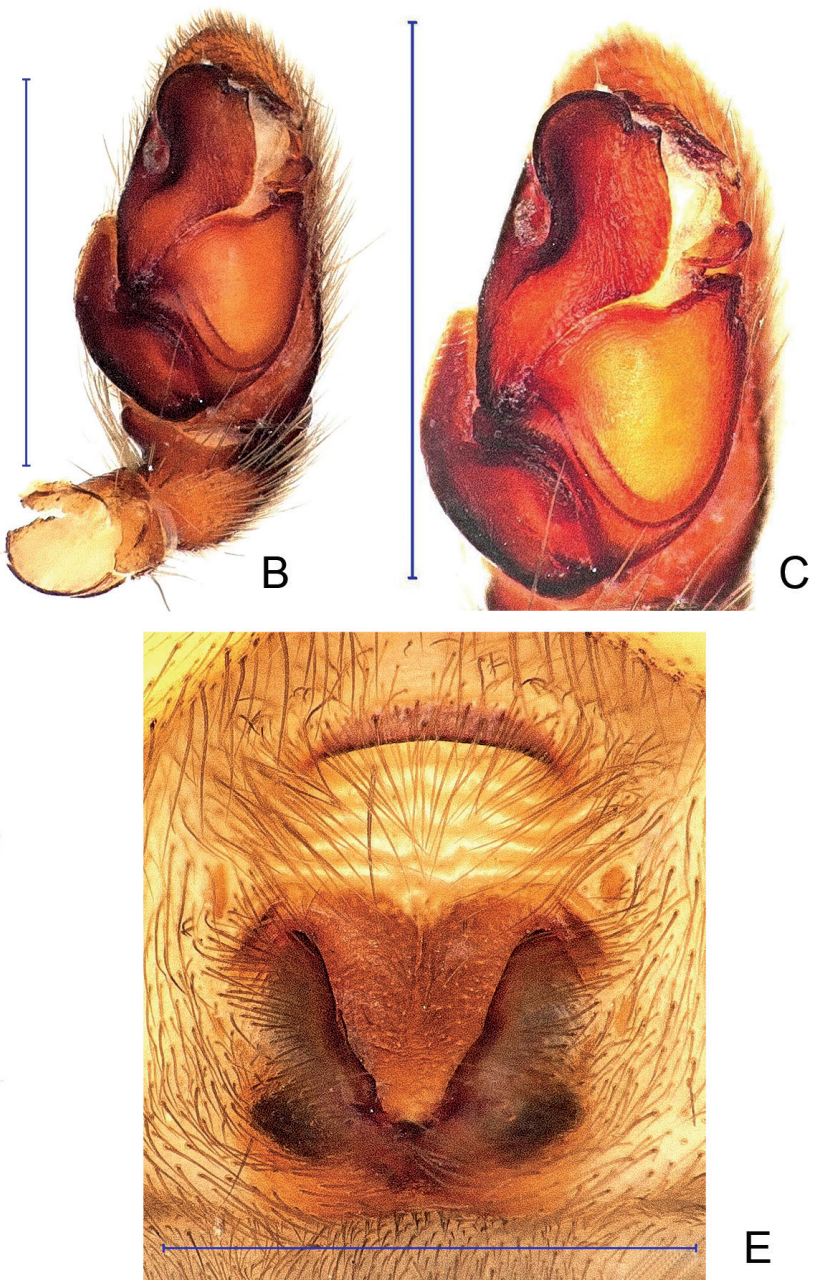

$\mathrm{E}$

Fig. 7. Halpodrassus moderatus: $\mathrm{A}-\mathrm{D}=$ male left palp, $\mathrm{A}=$ retrolateral, $\mathrm{B}=$ ventral, $\mathrm{C}=$ bulbus, ventral, $\mathrm{D}=$ dorsal; $\mathrm{E}=$ epigyne, ventral. Scale bars: $1 \mathrm{~mm}$ 

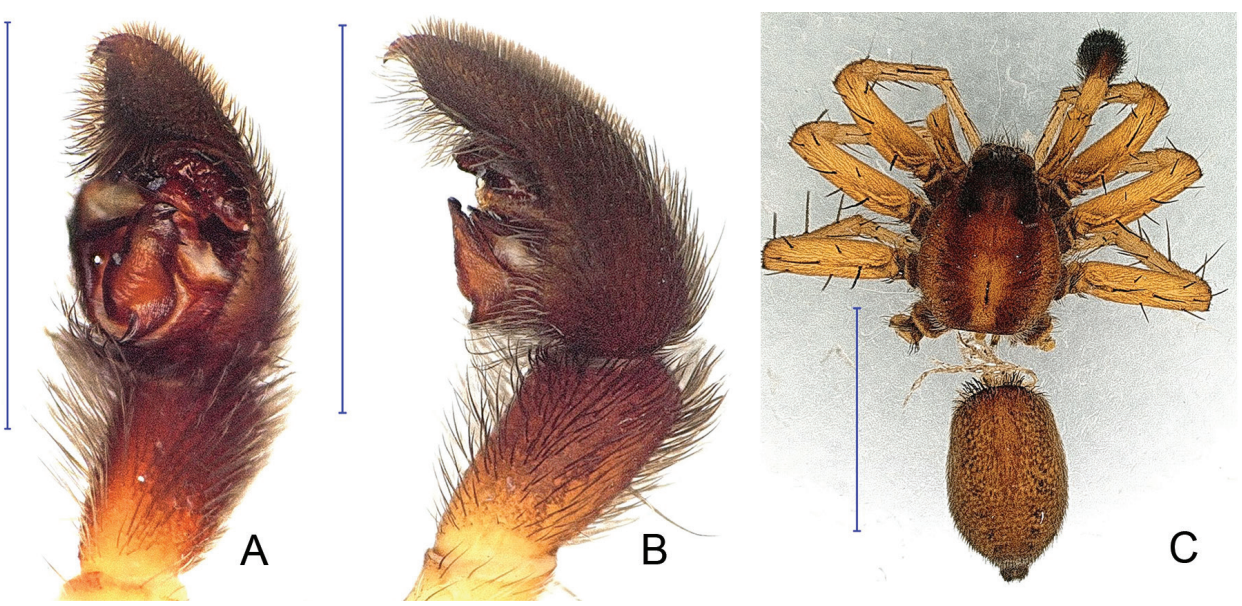

Fig. 8. Pardosa maisa, male, $\mathrm{A}, \mathrm{B}=$ mal left palp, $\mathrm{A}=$ ventral, $\mathrm{B}=$ lateral, $\mathrm{C}=$ male, habitus.

Scale bars: $1 \mathrm{~mm}$ for $\mathrm{A}-\mathrm{B}, 3 \mathrm{~mm}$ for $\mathrm{C}$

\section{Family Linyphiidae}

Canariphantes nanus (Kulczyński, 1898)

Material: 30.5.2014 F 1ठ; 30.5.2014 M3

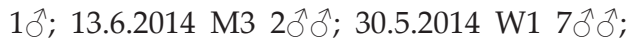

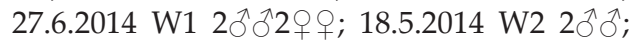
30.5.2014 W2 15Љð1우; 27.6.2014 W2 6우; 30.9.2014 W2 1우 27.4.2014 W3 1ð̊; 30.5.2014 W3 $6 \overbrace{}^{\lambda} 2$ 우우; 27.6.2014 W3 4 웅 30.9.2014 W3 1ठ; 30.5.2014 W4 2우; 30.9.2014 W4

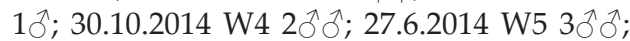

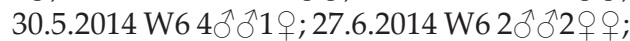
16.7.2014 W6 1ठ; 16.8.2014 W6 $1 \delta^{\lambda}$.

Determination: Miller 1947, LoKsA 1981, GNeliTSA 2009.

Global distribution: Central to Eastern Europe.

Habitat: The species was found on the ground in a litter, grass and moss in xerothermic, steppe-like habitats but also in deciduous woods (Gnelitsa 2009, Komnenov 2014, Polchaninova et al. 2017) and in oak forest close to our sampling area in Hungary (BALi et al. 2017).

Note: Even if the female was described quite early (KuLCZYŃsKi 1898) from Lower Austria and the male from the southern Czech Republic (Miller 1947) it seems to be

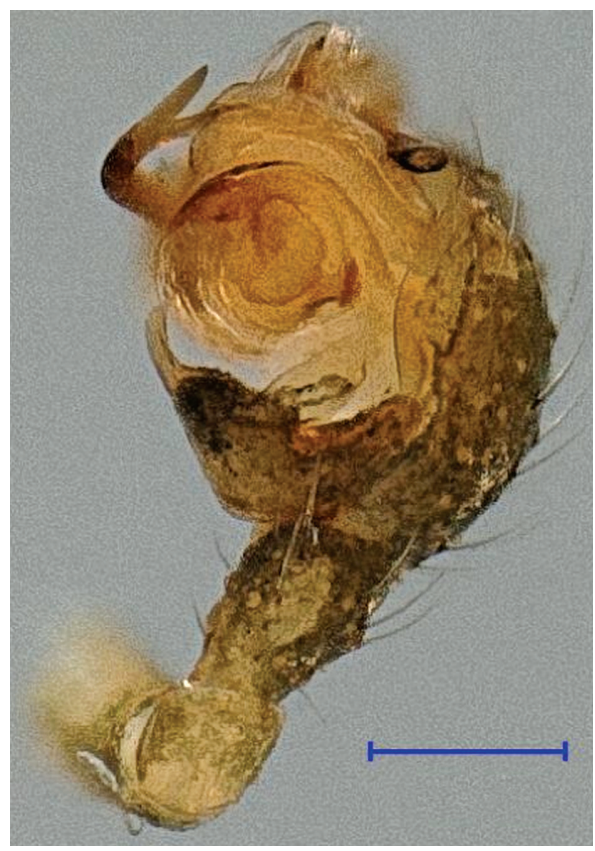

Fig. 9. Canariphnates nanus, male left palp, retrolateral. Scale bar: $0.1 \mathrm{~mm}$ 
collected only rarely (but see Gnelitsa 2009, and BALI et al. 2017). In our investigation, we found it in high numbers (73 individuals), in all woody habitats, on a meadow and even in a field of Carex spp. Canariphantes nanus was described in detail by GNeLiTsa (2009) and may be easily identified by the typical lamella characteristica and paracymbium of the males (Fig. 9). This species appears only in the Red List of the Czech Republic in the category critically endangered.

\section{Glyphesis taoplesius Wunderlich, 1969}

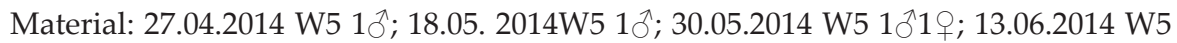
$1{ }^{\Uparrow} 2$ 우우; 27.06.2014 W5 1우.

Determination: Wunderlich 1969, ÉNeKESOvá et al. 2011, OleszCZuK et al. 2011.

Global distribution: Europe.

Habitat: Prefers humid conditions, in damp woodland and moss of bogs HäNGGi et al. (1995), and the reed belts of Lake Velence (KANCSAL et al. 2010) and Lake Balaton (BLICK \& SzINETÁr 1996) in Hungary.

Note: For comprehensive discussions of this rare, hygrophilous species see OleszCzUK et al. (2011) and ÉNEKESOvÁ et al. (2011). In addition to the figure of the male palp in OLESZCZUK et al. (2011) and photos in ÉNEKESOvÁ et al. (2011) (male palp in unusual angles, epigyne as SEM only) we add photos of the male palp in retrolateral view and the epigyne in situ (Fig. 10).

In the Subotica Sandland G. taoplesius was recorded in the flooded forest of white and grey poplar (Populus alba + Populus canascens) (W5) with a high level of groundwater. This very stenoecious and rarely found species should be included in the list of Serbian protected spiders and monitored in the future. In Germany, the species is classified as critically endangered in the Red List of species.

\section{Gongylidiellum murcidum Simon, 1884}

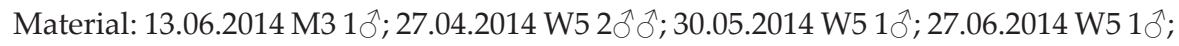
16.07.2014 W5 1우.

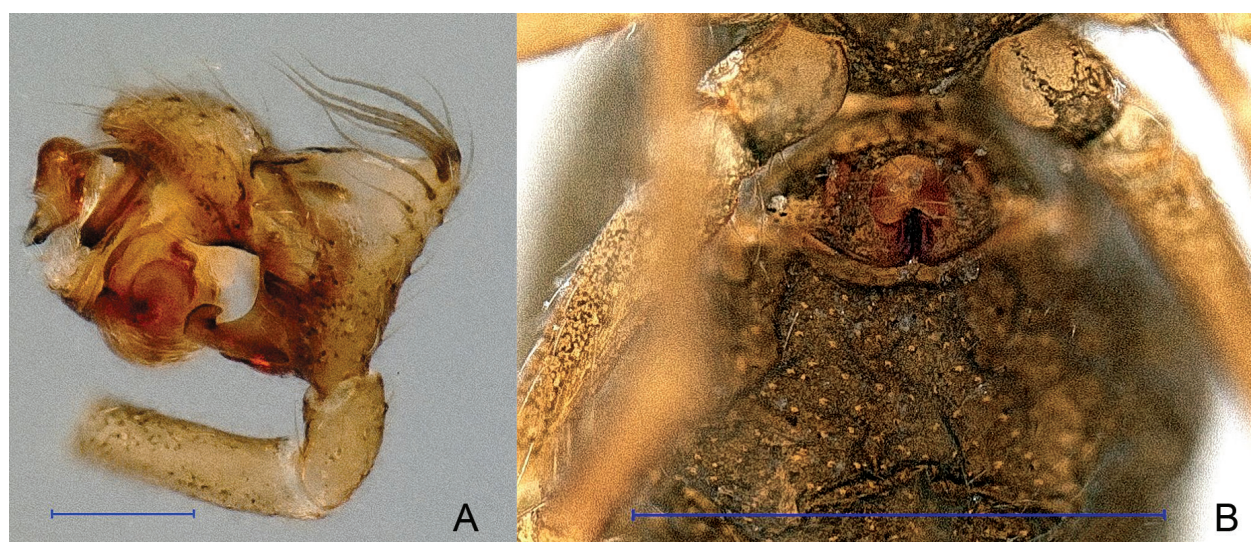

Fig. 10. Gylphesis taoplesius: $\mathrm{A}=$ left male palp, retrolateral, $\mathrm{B}=$ epigyne in situ. Scale bars: $0.1 \mathrm{~mm}$ for $\mathrm{A}, 0.5 \mathrm{~mm}$ for $\mathrm{B}$ 
Determination: WieHLe 1960, Roberts 1987.

Global distribution: Palaearctic.

Habitat: In moss and litter layer of lowland forests, in humid conditions.

Note: This species is widely distributed all over the lowlands of Europe yet relatively rarely found (Nentwig et al. 2020). The species is widely distributed in Europe, but up to date (?) missing in the western Balkans. It is classified as vulnerable in the Czech Republic and England, but not endangered in other countries.

\section{Hypsocephalus pusillus (Menge, 1869)}

Material: 30.05.2014 M3 1․

Determination: Miller 1966, Millidge 1978, Gnelitsa 2009.

Global distribution: Europe (but missing in the western countries).

Habitat: Various dry habitats, from forest to steppe (GNelitsa 2009).

Note: Hypsocephalus pusillus (syn $=H$. dahli) is a very small (body length $1.1 \mathrm{~mm}$ ) linyphiid spider inhabiting xerothermic sites (Frick 2008, Frick \& Starega 2009, Gnelitsa 2009). The habitat of our specimen (M3, peat meadow) is not typical compared to data from the literature. In Germany and the Czech Republic, the species is listed as endangered in the Red List of species.

\section{Mermessus trilobatus (Emerton, 1882)}

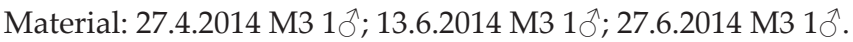

Determination: Helsdingen van 1982, Oger \& Picard 2014, Šestáková et al. 2017.

Global distribution: North America, Europe, introduced to Azores.

Habitat: In nearly all open habitats.

Note: Originally from North America and widely distributed. It is assumed that it was imported into south-western Germany in the 1980s by the US Army (first records for Europe in Germany by Dumpert \& Platen 1985) and in Switzerland (Hänggi 1990) and dispersed from there (Hirna 2017). Mermessus trilobatus was recorded in European countries equally in natural and non-natural ecosystems (Hirna 2017). In our study, it was recorded at M3 habitat a lowland peat meadow. The potential influence of such an invasive species on the structure of native spider communities in the Subotica Sandland is unknown and should be monitored in future.

\section{Panamomops mengei Simon, 1926}

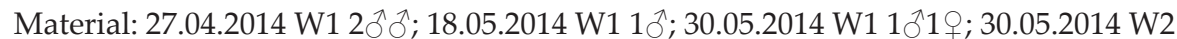

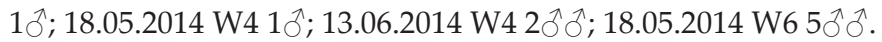

Determination: Wiehle 1960, Miller 1971, Nentwig et al. 2020.

Global distribution: Palaearctic.

Habitat: In moss and litter of dry, rather clear forests.

Note: Rarely found (Nentwig et al. 2020). Serbia is at the southern range of the distribution of Panamomops mengei that seems to prefer a temperate (continental) climate. The species is listed as not endangered in Germany, Sweden and the Czech Republic. 


\section{Porrhomma oblitum (O. P.-Cambridge, 1871)}

Material: 30.05.2014 W5 2 우.

Determination: ThALER 1968, RoBerTs 1987, RŮžIČKa 2018.

Global distribution: Central Europe.

Habitat: In wet open and forest habitats (RŮŽIČKA 2018), but also in agricultural habitats, especially intensively used meadows (HäNGGI et al. 1995).

Note: According to the European distribution range presented in Nentwig et al. (2020) it was expected in Serbia. The species is listed as not endangered in Germany and the Czech Republic.

\section{Sintula spiniger (Balogh, 1935)}

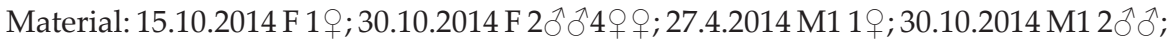
30.09.2014 M2 1; 30.10.2014 M2 1ð1; 13.06.2014 M3 2우; 16.09.2014 M3 1; 30.09.2014

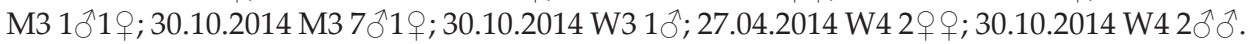

Determination: Balogh \& Loksa 1947, Miller 1968, Gnelitsa 2012.

Global distribution: Southern and eastern Europe.

Habitat: In leaf litter of open deciduous forests. On rock and sandy steppes.

Note: Very rarely found (Nentwig et al. 2020). The habitat preference and biology of this species is still not clear. In Bulgaria, it could be found in mountains up to $1000 \mathrm{~m}$ (habitats Quercetum, Carpinetum) and is considered very rare, but in Slovakia, it is not rare in dry calcareous grassland with shrubs (GNeliTsa 2012). In Hungary, the species was found in sandy steppes (Festucetum vaginatae danubiale) (SzInetár et al. 2009). In Ukraine, Sintula spiniger was found in a mixed forest, pine forest, at a river bank and flood-land forest (GNELITSA 2012). In our study, this species was found in 5 different habitats: (F), (M3), (M1),
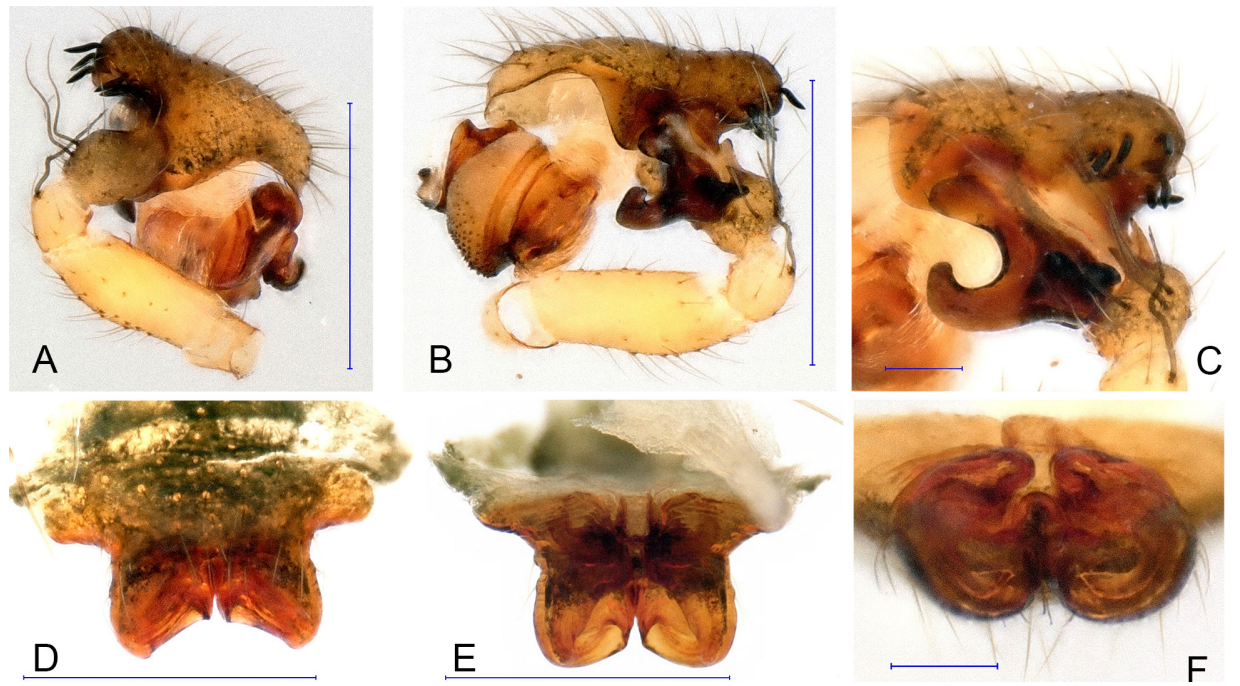

Fig. 11. Sintula spiniger, $A-C$ male left palp, $A=$ prolateral, $B=$ retrolateral, $C=$ paracymbium, $\mathrm{D}-\mathrm{F}=$ female epigyne, $\mathrm{D}=$ ventral, $\mathrm{E}=$ dorsal, $\mathrm{F}=$ aboral. Scale bars: $0.5 \mathrm{~mm}$ for $\mathrm{A}-\mathrm{B}$, $0.1 \mathrm{~mm}$ for C, $0.4 \mathrm{~mm}$ for D-E, $0.1 \mathrm{~mm}$ for $\mathrm{F}$ 
(M2), and (W3) (W4). According to Nentwig et al. (2019), it is distributed around Serbia, but in total, just in a few countries of central and Eastern Europe. S. spiniger is well described by Gnelitsa (2012), and we just add some photos of this very characteristic species (Fig. 11). The species is listed as endangered species in the Czech and Slovakian Red List of species.

\section{Syedra apetlonensis Wunderlich, 1992}

Material: 18.05.2014 M2 1ð.

Determination: WundeRLICH 1992.

Global distribution: Austria, Slovakia, Russia.

Habitat: In non-pastured meadow.
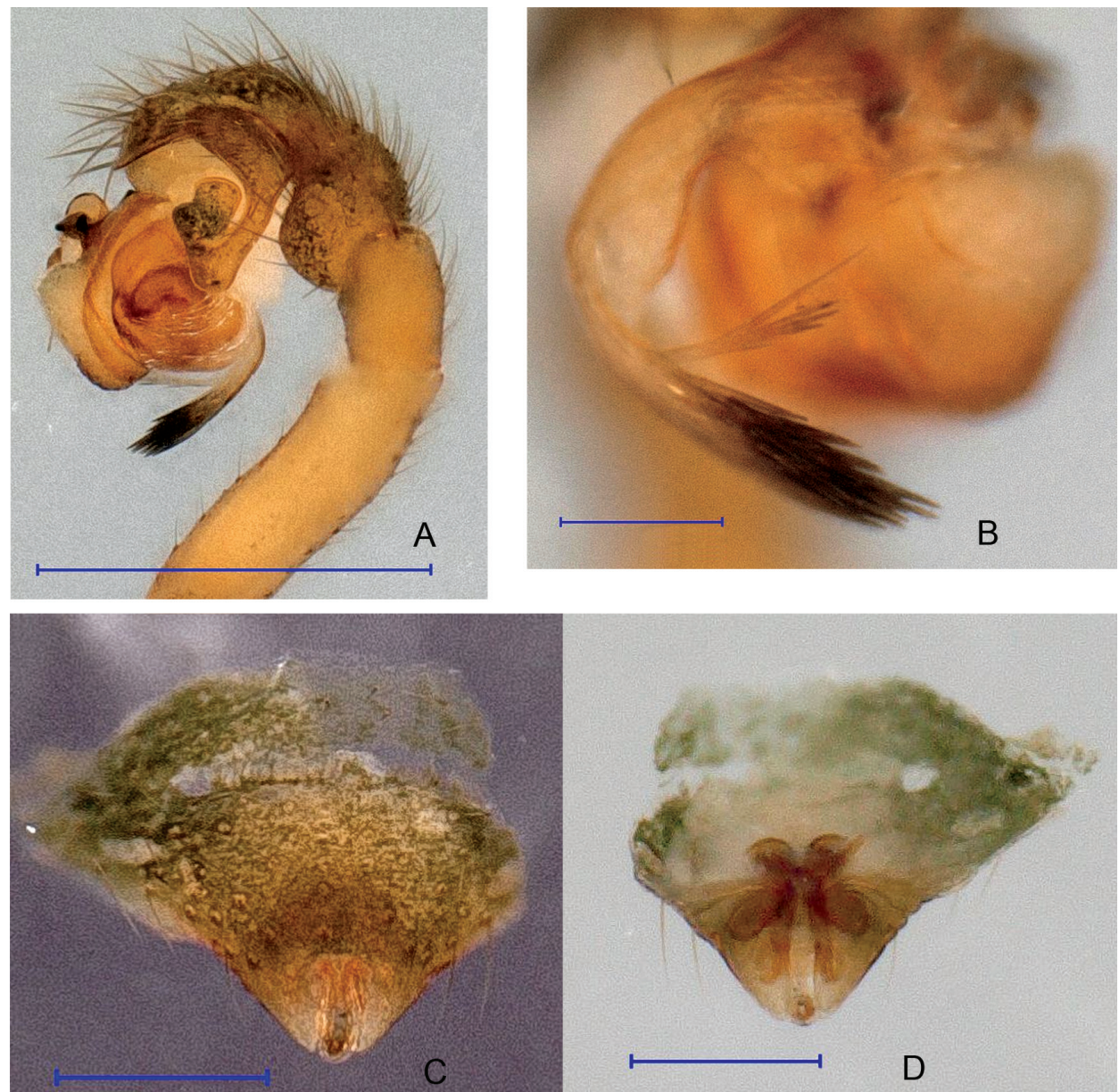

Fig. 12. Tallusia vindobonensis, $\mathrm{A}-\mathrm{B}=$ male left palp, $\mathrm{A}=$ retrolateral, $\mathrm{B}=$ detail of the lamella characteristica, $C=$ female epigyne, $\mathrm{D}=$ vulva dorsal. Scale bars: $0.5 \mathrm{~mm}$ for $\mathrm{A}, 0.1 \mathrm{~mm}$ for B, $0.2 \mathrm{~mm}$ for $\mathrm{C}-\mathrm{D}$ 
Note: Very similar to the species Syedra myrmicarum (Kulczyński, 1882), and sometimes misidentified (AAKRA et al. 2016). According to the literature listed in AAKRA et al. (2016), this species can be found in dry non-pastured meadows, steppe and meadows but also in bird nests, and has been considered to be a Central European endemic. Its similarity in habitus to other known myrmecophile linyphiids (i.e. pale brownish overall color, unmodified carapace, etc.) suggest that this species could exhibit this lifestyle too, even if this has not been recorded in the literature (AAKRA et al. 2016). In our material, it was found in meadows. This species is not treated in any of the consulted Red List of species.

\section{Tallusia vindobonensis (Kulczyński, 1898)}

Material: 30.10.2014 M2 1; 30.10.2014 M3 1ð1우.

Determination: Polenec \& Thaler 1980, Thaler 1997, Gajdoš et al. 2019.

Global distribution: Europe.

Habitat: Various types of habitats, from lowland to upland (GAjDoš et al. 2019).

Note: Very rarely found, reproduction period in winter (NeNTwig et al. 2020). GAjDoš et al. (2019) summarise the known ecological data: males adult in winter, females through all the year; different types of meadows (nutrient-poor, karst meadows and but also salt marshes. In our material Tallusia vindobonensis was found in the wet meadows (M2, M3). For the determination and separation from Tallusia pindos Thaler, 1997 (see Polenec \& Thaler 1980 and Thaler 1997). Some photos of the male palp and the female epigyne/ vulva underline the identification (Fig. 12). This species is not treated in any of the consulted Red List of species.

\section{Walckenaeria atrotibialis (O. P.-Cambridge, 1878)}

Material: 27.6.2014 W5 1ð1ㅇํ.

Determination: Wiehle 1960, Wunderlich 1972, PAquin \& Dupèrrè 2003.

Global distribution: Holarctic.

Habitat: Found in a very large range of habitats.

Note: According to Nentwig et al. (2020) this species is „relatively rarely found”, but see HäNGGI et al. (1995) with more than 50 citations for the species from many habitats. The fact that the species is hardly known from the Balkans is probably due to less frequent investigations compared to Central Europe. The species is not endangered in Germany and the Czech Republic.

\section{Family Miturgidae Zora armillata Simon, 1878}

Material: 18.05.2014 F 1; 13.06.2014 F 1우 16.07.2014 F 4우우 30.07.2014 F 1우;

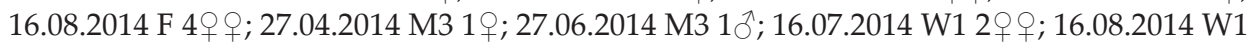

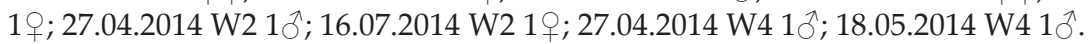

Determination: Almquist 2006, Heimer \& Nentwig 1991, Tullgren 1946.

Global distribution: Palaearctic.

Habitat: Wet and moist habitats (Almquist 2006), dwarf shrub heath.

Note: According to Almquist (2006) and AaKra et al. (2016) this species is usually associated with wet and moist habitats. However, in our material, it was found equally at 
wet (habitats F, M3) and in rather dry (habitats W1, W2, W4) areas. Zora armillata is listed as nearly threatened in Sweden, endangered in Germany but critically endangered in England and the Czech Republic.

\section{Zora parallela Simon, 1878}

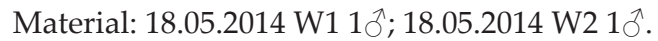

Determination: Heimer \& Nentwig 1991, Pozzi \& Hänggi 1998, Almquist 2006, ZamANI \& MARUSIK 2017.

Global distribution: Palaearctic.

Habitat: Xerothermic open habitats.

Note: There are some different habitat records: peat bogs (Ḧ̈NGGI et al. 1995), in old wastelands covered with bushes (Pozzi \& HäNGGI 1998) or grasslands and overgrowth of limestone karst plateaus (Gregorič \& Kuntner 2009). Recently it was reported from Bulgaria (Naumova et al. 2017) with no habitat description. Adults were found in May and June, females until October (SvatoŇ et al. 2009). In our material, this species was recorded in fragments of wood (habitats W1 and W2). In the Red List of species this species is classified in several different categories: near threatened (Sweden), endangered (Czech Republic), vulnerable (Finland), and critically endangered (Germany).

\section{Family Philodromidae Pulchellodromus ruficapillus (Simon, 1885)}

Material: 13.06.2014 M3 1ð; 16.07.2014 M3 1ㅇ․

Determination: Muster et al. 2007, Kastrygina \& Kovblyuk 2014, Mezőfi \& Markó 2018. Global distribution: Mediterranean to Kazakhstan. al. 2007).

Habitat: Usually in wetlands or along riverbanks and also on seashores (Muster et

Note: This species was thoroughly redescribed by Muster et al. (2007) as Philodromus ruficapillus in the revision of the P. pulchellus species-group, but 7 years later (KastrYGina \& Kovblyuk 2014) it was redirected into the Pulchellodromus species group. According to Muster et al. (2007) in contrast to most other running crab-spiders that live on stems or foliage of woody plants, this spider is predominantly a ground-living predator. Some of the old records that Muster et al. (2007) rechecked suggested a preference for wetlands, but Kastrygina \& Kovblyuk (2014) found the species in semi-desert steppe in the Crimea. In our material, P. ruficapillus was found in lowland peat meadows situated along the border with Hungary and the Körös River, with the dominant plant association being Molinietum caeruleae. This species is not treated in any of the consulted Red List of species.

\section{Thanatus striatus C. L. Koch, 1845}

Material: 27.06.2014 F $1 \hat{\jmath}$.

Determination: Logunov 1996, Szita \& Samu 2000, Muster \& Thaler 2003.

Global distribution: Holarctic.

Habitat: Often relatively frequent in damp meadows, on sea coasts and in swamps.

Note: Considered as endangered in the British and Slovakian Red List of species, but of least concern in other countries. 


\section{Family Salticidae \\ Aelurillus v-insignitus (Clerck, 1757)}

Material: 27.04.2014 M1 1ð, 30.05.2014 M1 1ð’; 30.07.2014 M1 1ㅇ.

Determination: Harm 1977, Weiss 1979, Roberts 1998, Metzner 1999.

Global distribution: Palaearctic.

Habitat: Xerothermic sunny, dry slopes, in sandy habitats, dunes and open woods.

Note: It is listed as not endangered in Sweden, Germany and the Czech Republic.

\section{Family Theridiidae}

\section{Theridion uhligi Martin, 1974}

Material: 13.06.2014 M2 1q; 16.07.2014 M2 10ิ.

Determination: Martin 1974, Jocqué 1977, Duma 2008, 2009.

Global distribution: Europe.

Habitat: In dry, sandy areas, with heather or pines (NeNTwig et al. 2020), in xerothermic grassland (DéjeAn 2012), the Pannonian calcareous sand steppes (cited in Gajdoš et al. 2019).

Note: In contrast to most known habitats, in our material, this species was found in a meadow (habitat M2). Wherever the species was found, it was captured in low numbers,

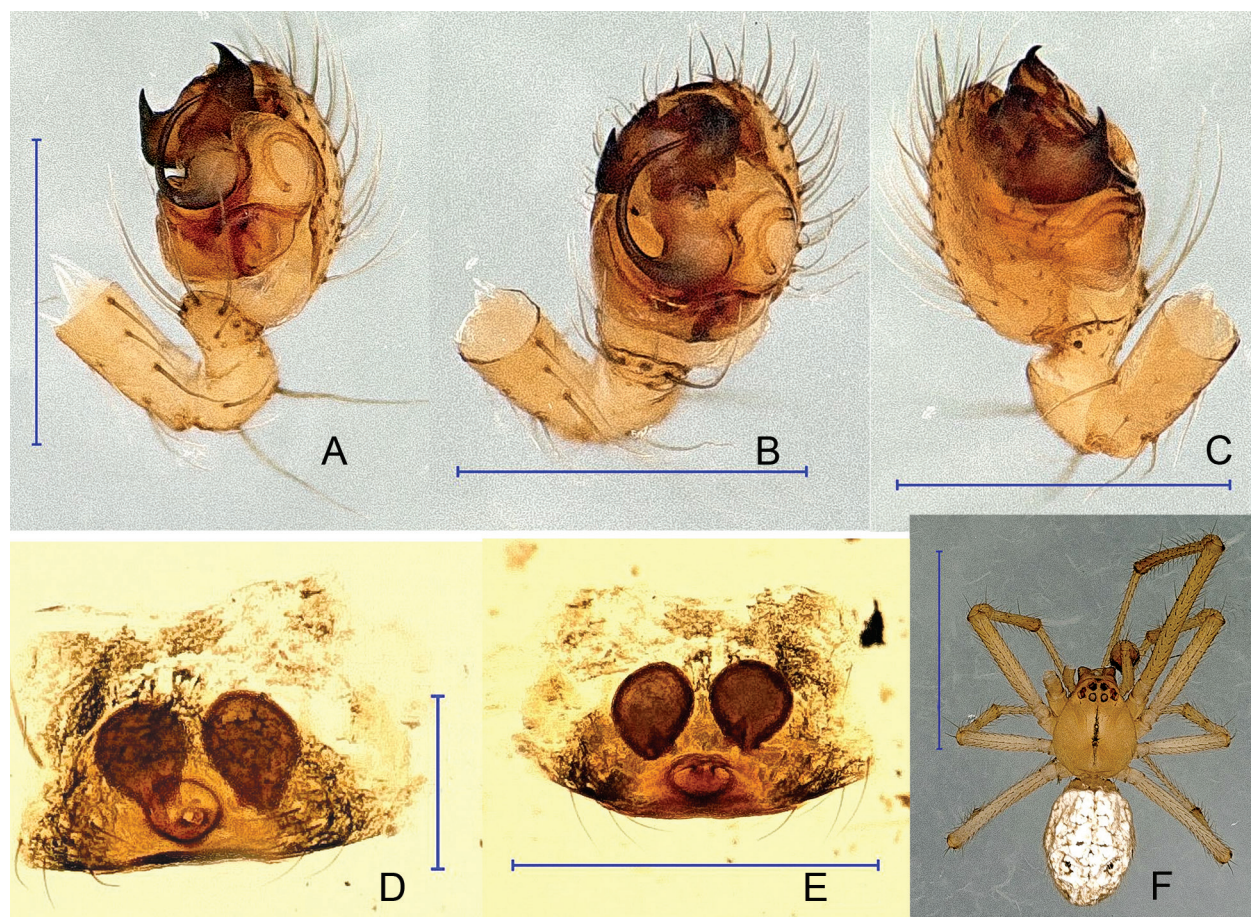

Fig. 13. Theridion uhligi, $\mathrm{A}-\mathrm{C}$ male left palp, $\mathrm{A}=$ retrolateral, $\mathrm{B}=$ ventral, $\mathrm{C}=$ prolateral, $\mathrm{D}-\mathrm{E}=$ female epigyne in clove oil, $\mathrm{D}=$ ventral, $\mathrm{E}=$ dorsal, $\mathrm{F}=$ male habitus. Scale bars: 0.5 $\mathrm{mm}$ for A-C, $0.2 \mathrm{~mm}$ for $\mathrm{D}, 0.5 \mathrm{~mm} \mathrm{E}, 1 \mathrm{~mm}$ for F 
and it is considered a rare spider (Duma 2008). Determination seems to be no problem in the male but for the female there exist drawings and photos with a quite different appearance, especially for the epigyne and the form of the receptacula. We, therefore, add some photos underlying our identification (Fig. 13). In Germany, the species is classified as critically endangered, but data on this species are very rare (BцICK et al. 2016), so a thorough evaluation is difficult.

\section{Family Thomisidae \\ Bassaniodes robustus (Hahn, 1832)}

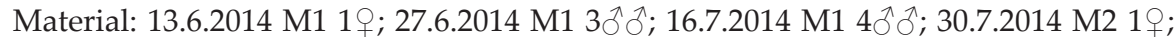

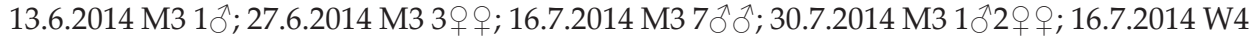

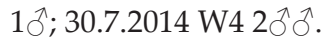

Determination: Tullgren 1944, Miller 1971, Roberts 1985.

Global distribution: Palaearctic.

Habitat: Xerothermic habitats, under stones, in short grass and moss, from lowlands up to the subalpine region.

Note: Based on barcode phylogenetic research, this species was recently transferred from Xysticus to Bassaniodes by Breitling (2019). According to Nentwig et al. (2020), this species is not frequent. It is noted in the Red lists as endangered (England) and vulnerable (Czech Republic), but not so (LC) in Sweden and Germany.

\section{Ozyptila brevipes (Hahn, 1826)}

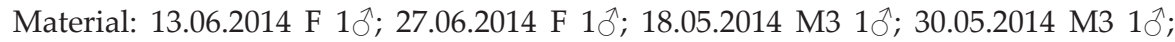
16.07.2014 M3 1ठ̊; 16.07.2014 W6 1ठ.

Determination: Miller 1971, RoberTs 1985.

Global distribution: Palaearctic.

Habitat: Wet, swampy areas.

Note: According to the ecological and geographical distribution in Europe this species was to be expected in Serbia. The species is listed as endangered in the Czech Republic and vulnerable in Germany but category LC in Sweden.

\section{Ozyptila trux (Blackwall, 1846)}

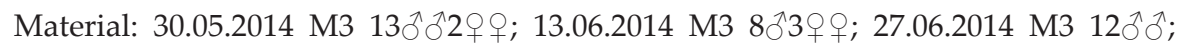

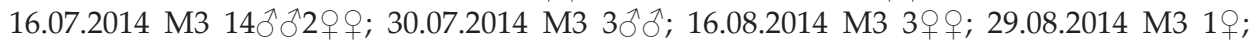

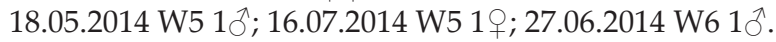

Determination: Dondale \& Redner 1975, Roberts 1985, Wunderlich \& Schultz 1995.

Global distribution: Palaearctic. Introduced to Canada.

Habitat: In various, open habitats.

Note: Widely distributed and frequent in Europe. Its existence in Serbia could have to be expected. The species is listed as not endangered in Germany, Sweden and the Czech Republic. 


\section{Family Titanoecidae}

Titanoeca spominima (Taczanowski, 1866)

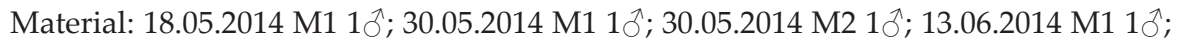

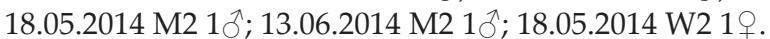

Determination: Wunderlich 1993, Roberts 1998, Alquist 2006.

Global distribution: Europe.

Habitat: On sandy ground with scarce vegetation.

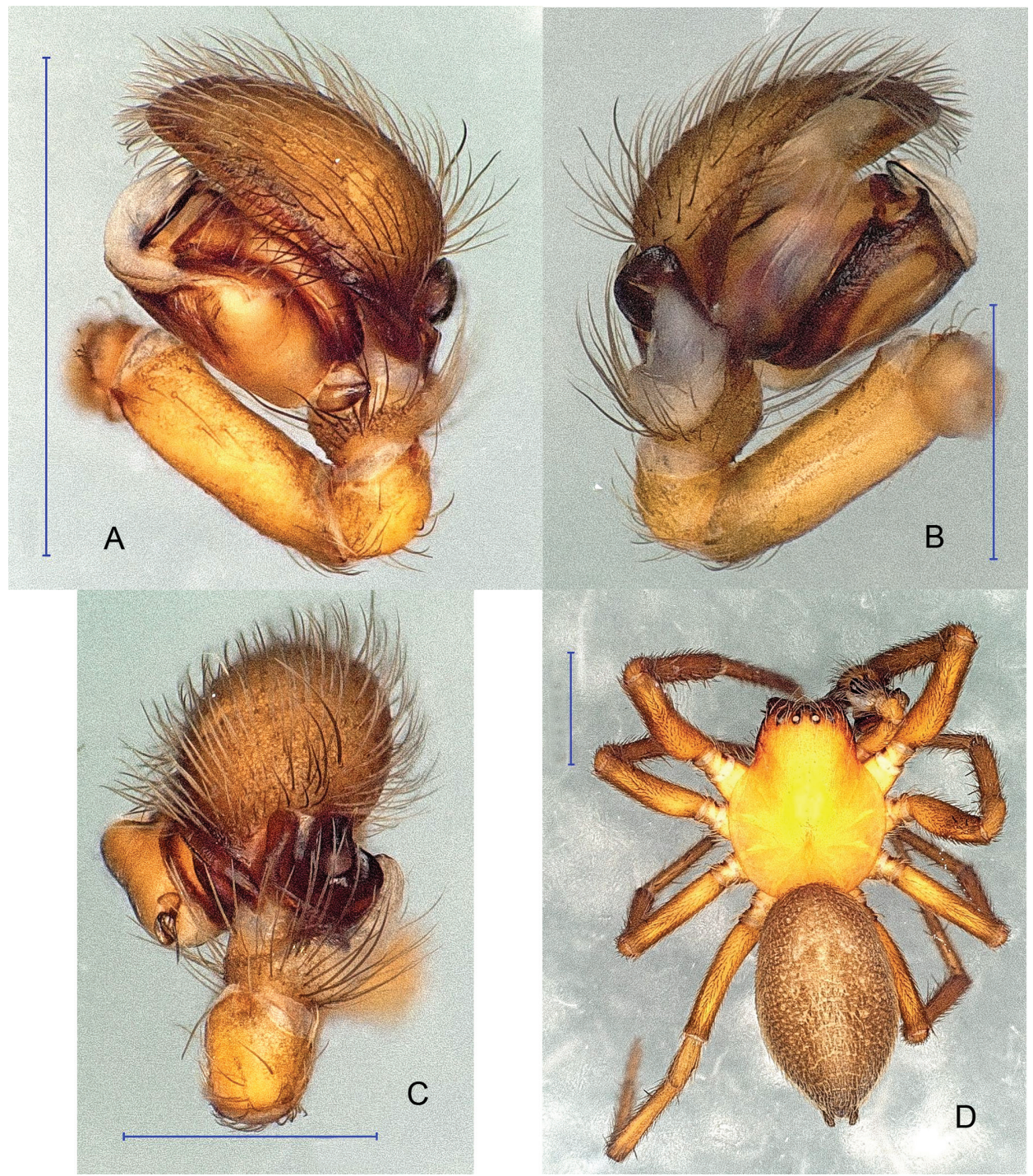

Fig. 14. Titanoeca spominima, $\mathrm{A}-\mathrm{C}=$ male left palp, $\mathrm{A}=$ retrolateral, $\mathrm{B}=$ prolateral, $\mathrm{C}=$ dorsal, $\mathrm{D}=$ male habitus. Scale bars: $1 \mathrm{~mm}$ for A, $0.5 \mathrm{~mm}$ for B-C, $1 \mathrm{~mm} \mathrm{D}$ 
Note: Wunderlich (1993) described the species Titanoeca psammophila Wunderlich, 1993, indicating that the species lives mainly on sand. BReITLING et al. (2015) synonymised the species with Titanoeca spominima, even if the original description of T. spominima is very poor and without figures. BreITLING et al. (2015) also noted that sandy dunes and meadows in different regions of Europe are typical habitats for this species. In our material, this species was recorded at the xerophilic steppe vegetation on brown sand (habitat M1), but also in the wet meadow (habitat M2) and in a young wood (habitat W2). Our specimen fit very well to the drawings in WUNDERLICH (1993). No photos of this strikingly coloured species exist, so we add some photos of the male palp and habitus (Fig. 14). In the Red List of species, it is classified as vulnerable (Sweden), critically endangered (Czech Republic), endangered (Germany), but also as near threatened (Finland).

\section{ECOLOGICAL OVERVIEW}

Species richness and composition

The richest habitat in species was M3 at Locality 3 with 120 recorded species, while the poorest was W3 at Locality 1, with only 40 species recorded. The order of all habitats concerning their species richness is as follows: M3 (120 species), M2 (96), W6 (68), F (67), M1 (67), W5 (49), W4 (48), W1 (42), W2 (41), W3 (40 taxa). It has to be mentioned that sweep netting was done only in the meadows as to get additional information for the species list. However, for nature protection more important than the species numbers per habitat are species compositions and the ecological qualities of the species in the observed habitat.

Locality 1 : The most interesting habitat at Locality 1 was the meadow M1 with 67 species ( 377 individuals) that represent almost $60 \%$ of all recorded species at this locality in only $5.7 \%$ of the total collected material here. A whole set of typical xerothermic species such as Argiope lobata, Oxyopes heterophthalmus, Bromella falcigera, Carrhotus xanthogramma and the typical sandland species Berlandina cinerea, Titanoeca spominima and Gnaphosa mongolica were recorded here. The last two are recorded for the first time in Serbia. Furthermore, two very rare species Haplodrassus bohemicus and Lathys stigmatisata were also recorded here. The dominant species in habitat M1 are O. heterophthalmus (31 individuals), Xysticus kochi (28), B. cinerea (28), Zelotes longipes (26) and Pelecopsis parallela (23). These are not the same dominant species as in the other habitats of this locality. This indicates the completely different environmental conditions of this habitat.

The other habitats of Locality 1 (W1-4) were more or less similar in species composition and diversity. Regular representatives of the forest habitats were Anyphaena accentuata, Araneus angulatus, Episinus truncatus, Gibbaranea biturberculata, Harpactea rubicunda, Zilla diodia. Furthermore, an invasive species Ostearius melanopygius, and a strictly protected species (by law) in Serbia (Official Gazette of RS, no. 5/2010, 47/2011, 32/2016, 98/2016) Porrhomma mi- 
crops, were reported. Also, a small but interesting difference was found in the habitat W3, where H. rubicunda appears among the dominant species and suppresses Zelotes apricorum into 6th place by abundance. Harpactea rubicunda is a typical Quercus wood species (LoKsA 1969), and W3 is an autochthonous mixt wood with a quite different structure of ground litter, due to the Quercus trees, compared to the deciduous W1 and W2 habitat of only Populus trees.

Locality 2: In the habitats of Locality 2 a set of Lycosids that are characteristic for humid environments was recorded. Primarily, those are species Pirata piraticus, Piratula tenuitarsis, Piratula hygrophila and Piratula latitans. Followed by Arctosa leopardus, Pardosa paludicola and Pardosa maisa. This clearly distinguishes this locality from the previous one and underlines the different environmental conditions.

In the wet Carex-field (F2) further hydrophilic species of other families were recorded, such as Dactylopistes digiticeps and Mendoza canestrinii. Two rare and, in the view of nature protection, important species were also recorded here: Clubiona rosserae is a very rare (DAwson 2011) species for which Subotica Sandland is also the first known place in Serbia and Dolomedes plantarius which is considered rare e.g. in Germany (BLick et al. 2016) and globally vulnerable according to the Red List (IUCN 2020).

With 96 species (573 individuals), the meadow (M2) is the most diverse habitat with $65 \%$ of all recorded species at this locality in only $12 \%$ of the total collected material here. The dominant species in this habitat are Hogna radiata (131 individuals), Trochosa ruricola (30), Xysticus kochi (25), Thanatus formicinus (25) and Evarcha arcuata (22). All these species are open land species that prefer warm habitats. So, the spider community in M2 is quite different from all other habitats. Two other rare species should be highlighted: Syedra apetlonensis, considered to be a Central European endemic species (AAKRA et al. 2016), and the poorly known Theridion uhligi (BLICK et al. 2016). The flooded wood (W5) shares some species with habitat F (Carex-field) indicating the very wet conditions. Two more species, both first records for Serbia, are very special for this locality: Glyphesis taoplesius that was only found in the wood W5 and Haplodrassus moderatus with 26 individuals in Carex field (F) and only one single female in the meadow (M2).

Locality 3: In the habitats of Locality 3 the dominant species mainly were hygrophilic, so-called wetland species: Pachygnatha degeeri, Pardosa prativaga, Tetragnatha montana, Piratula hygrophila, P. latitans, Arctosa leopardus and Pardosa paludicola. Furthermore, some species that are typical of sunny meadows near open water were recorded at the habitat M3 such as Hypsosinga pygmaea, Larinioides cornutus and Singa lucina. The latter is considered rare by LoKsA (1972). Also, the invasive species Mermessus trilobatus was recorded at habitat M3, while the legally strictly protected Porrhomma microps was caught at both 
habitats (M3, W6). The two rare and poorly known species Hypsocephalus pusillus, a species restricted to Central Europe (Nentwig et al. 2020) and Pulchellodromus ruficapillus, a specialist of wet habitats (Muster et al. 2007), represent further species of this locality as new records for Serbia.

\section{Habitat diversity and similarity}

The calculated diversity measures for all habitats (Fig. 15) showed that very high values of $\mathrm{H}^{\prime}, \mathrm{E}$ and 1-D indexes were registered for the sandy, xerothermic meadow M1 (Locality 1 ) and the meadow M2 (Locality 2). The peat meadow (M3), the wet shrubby habitat (W6), the Carex meadow (F) and the flooded wood (W5) showed medium values for $\mathrm{H}^{\prime}, \mathrm{E}$ and 1-D. The lowest values are found in the xerothermic woods at Locality 1 (W1-4).

Ten habitats were chosen to represent different habitat types with different plant associations and ecological characteristics, especially ground humidity. The spider communities accordingly show apparent differences in species composition. A dendrogram of the similarities between the habitats based on a similartity index taking into account the abundances of the species (Renkonen index) is presented at Fig. 16. The four woods of the dry Locality 1 clearly group together (W1-4) while the flooded wood (W5) and the shrubbery near the pond (W6) are somewhat isolated. The open habitats that all differ quite a lot according to ground humidity and plant structure are clustering in two groups at a rather low level, indicating that the spider fauna of each open habitat is very specialised, but also clearly separated from the wooded habitats.

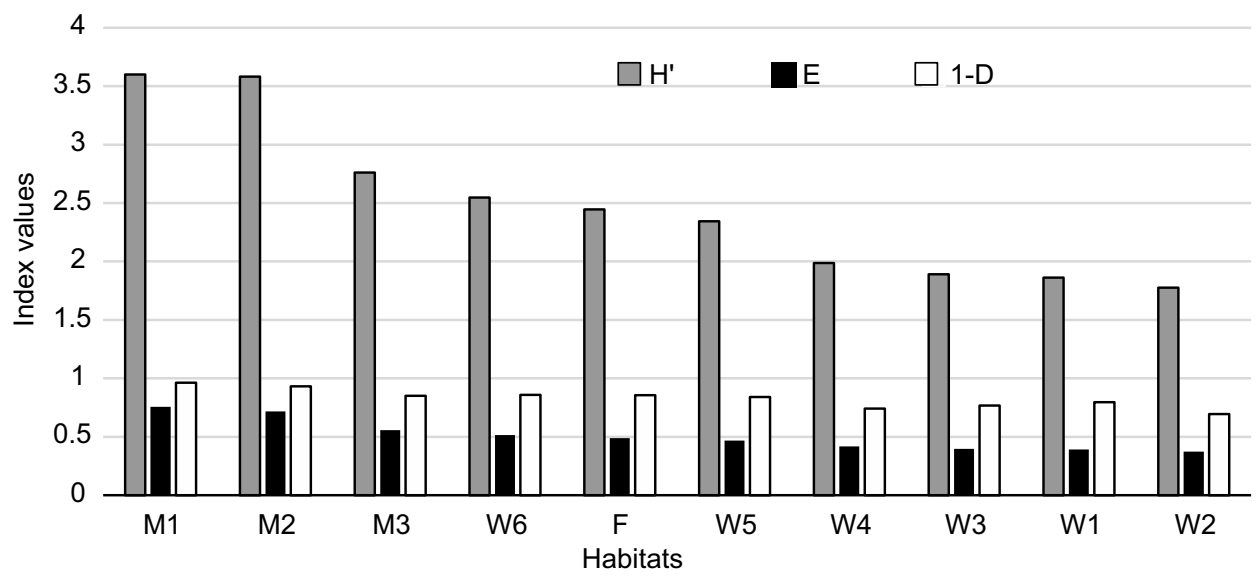

Fig. 15. Diversity indexes for the habitats at Subotica Sandland investigated in 2014. Shannon-Weaver's Diversity Index $\left(\mathrm{H}^{\prime}\right)$, Shannon's Equality Index of Species (E), the complement value of Simpson's Diversity Index (1-D); Locality 1 (habitats M1,W1-4), Locality 2 (M2, F, W5), Locality 3 (M3, W6) 


\section{DISCUSSION}

Discussion of the faunistic findings

The number of spider species (225) collected at Subotica Sandland in only ten habitats is quite high. According to the literature available from Serbia (Deltshev et al. 2003, Tomić \& Grbić 2008, Grbić \& Savić 2010, Grbić et al. 2011, 2015, 2019, Dudić et al. 2013, GAJIĆ \& GrBić 2016) this is the most species-rich study site yet known in this country. Furthermore, compared with Kiskunság National Park in Hungary (Loksa 1987, Kerekes 1988, Szita et al. 2005, BALr et al. 2017) whose sands extend from the border with Subotica Sandland to Budapest, our habitats share 143 spider species with the Hungarian part of the landscape. However, in our study, we did not find Dictyna szaboi Chyzer, 1891, identified by LoKsa (1987) as typical sandy and saline species of the Great Plane, nor the giant European wolf spider Lycosa singoriensis (Laxmann, 1770) recorded by LoKsA (1987) and KereKes (1988). The recording of both species in further investigations in this area is predicted. Furthermore, we already have (undocumented) information that L. singoriensis lives here (pers.com. Szekeres Ottó, P.C "Palić-Ludaš"). If that species is recorded, it

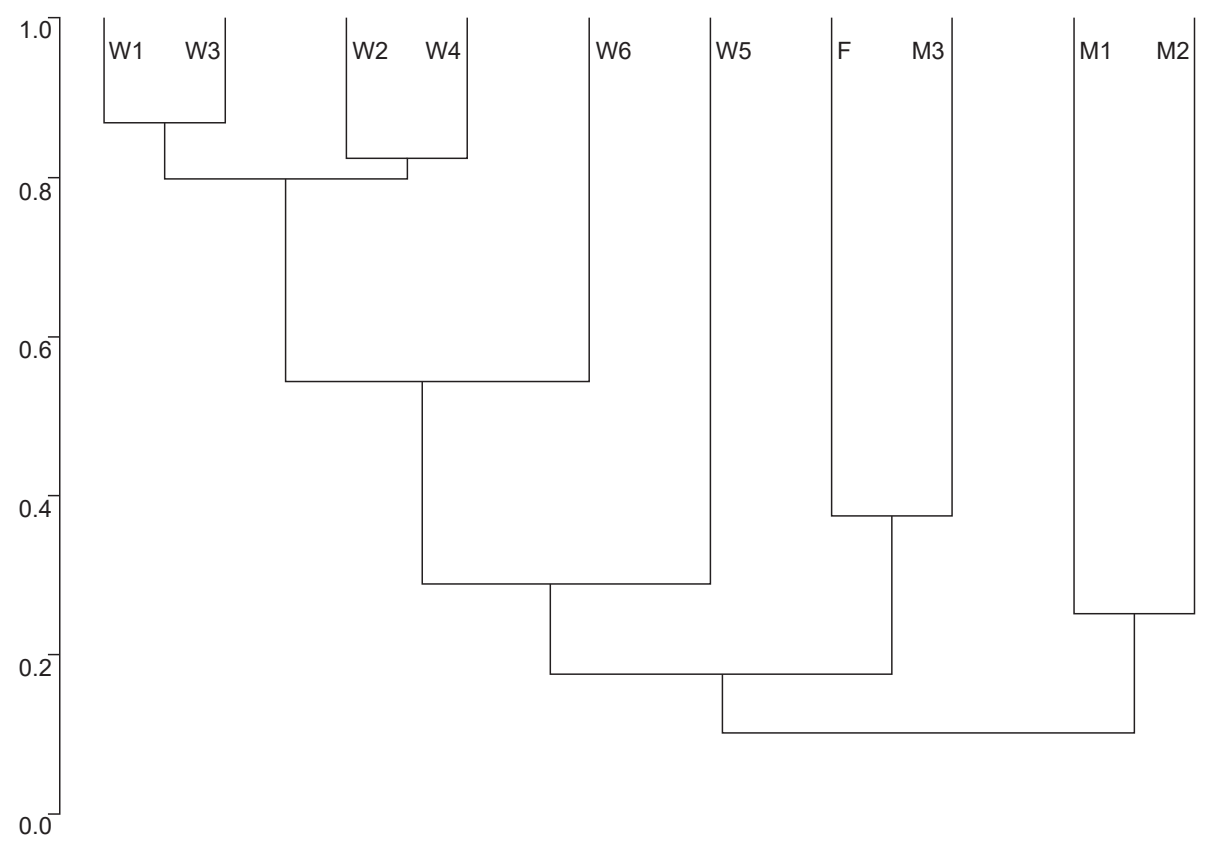

Fig. 16. Dendrogram (UPGMA-clustering) of the Renkonen indexes for the habitats at Subotica Sandland investigated in 2014. Locality 1 (habitats M1,W1-4), Locality 2 (M2, F, W5), Locality 3 (M3, W6) 
may be suggested as flagship species following the recommendations of $\mathrm{MI}_{\mathrm{I}}$ LASOWSZKY and ZuLKa (1998).

The large number of new species records for Serbia (30) indicates the high specificity of the Subotica Sandland even if we accept that the Serbian spider fauna is still insufficiently known. Data of Deltshev et al. (2003), subsequent publications up until 2019 listed above, together with our new species records have increased the total number of species in Serbia to 750. However, compared to neighbouring countries this number is rather moderate because the known number of species are in Hungary are 812 (Pfliegler et al. 2012, Nentwig et al. 2020), Albania 569 (Kůrka et al. 2020), and Montenegro 289 (Naumova et al. 2019). For Bulgaria (1046) (Naumova et al. 2017, Blagoev et al. 2018, Nentwig et al. 2020) and Romania (973) (Weiss \& Petrișor 1999) the situation is somewhat better. If we bear in mind that Serbia is part of the Balkans, which is a European centre of biodiversity, it is reasonable to expect that future intensive research all over Serbia will increase this number significantly.

About half of those species which are "new to Serbia" could have been expected because of their European distribution and ecological demands. However, some of these records are still notable. For example, findings of Haplodrassus moderatus are important in terms of geographical distribution, since this is the most southerly record in Europe. From a nature conservation point of view, Panamomops mengei is important because it is considered as a rare species (Nentwig et al. 2020). Lathys stigmatisata and Bassaniodes robustus are considered "not very common" (Nentwig et al. 2020); thus, it is favourable that these first records are in a protected area.

Unfortunately, the future of all those newly discovered species is uncertain. According to the literature (INPs 2003) human activities such as the development of irrigation canals without supervision, influences the network of underground water and changes the hydrological regime of such habitats which can result in biodiversity loss. Thus, in the near future, a paradoxical situation could occur: recently discovered spider species in the Subotica Sandland might be lost forever. It is important to continue with special measures related to the conservation and enhancement of natural species to avoid this situation. Those measures (clear-cutting, mowing, grazing with a special plan and program) as actually conducted by the Public company "Palic-Ludas" should be continued or even intensified, as should the prevention of illegal human activities by other competent institutions.

Lastly, since Serbia will not be able to provide a Red List of spider species based on very detailed knowledge for quite some time due to insufficiency of data, an update of the current List of protected species ("OfFicial GazetTe of RS", no. 5/2010, 47/2011, 32/2016) and 98/2016) should be considered, so that the paradoxical "new-but lost forever" situation will not happen. 


\section{Discussion of ecological findings}

A lot of typical representatives for the given environmental conditions were found in the studied habitats. Additionally, two other invasive species were found too e.g. Ostearius melanopygius (RozwaŁka \& Stachowicz 2010, El-Hennawy et al. 2016), originally from New Zeland and Mermessus trilobatus (Helsdingen \& IJLAnd 2007, Hirna 2017) originally from USA. These are not unexpected findings, since they have been present in Europe for several decades (Hirna 2017), but their influence on the autochthonous population is unknown. Also, the strictly protected species Porrhomma microps (by Serbian law) has been recorded. Furthermore, we found some species that are very rare all over Europe and difficult to collect, such as Syedra apetlonensis and Clubiona rosserae. Apart from C. rosserae all these species are very small, and sometimes difficult to identify. In contrast, there are also some larger species which are highly specialised relating to ecological conditions. These are the xerothermic Argiope lobata or the hygrophilic Dolomedes plantarius.

The selection of the investigated areas included xerothermic/steppe-like habitats as well as humid ones. The humid ones are well documented by species such as Dicymbium nigrum, Pachygnatha degeeri, Pardosa prativaga, Piratula hygrophilus, Pirata piraticus and Trochosa ruricola. All these species, typical for humid meadows (HäNGGI et al. 1995) indicate that the habitats of localities 2 and 3 have adequate hydrological characteristics for wetland species. However, the appearance of species such as Alopecosa cuneata, A. mariae, Arctosa figurata, Berlandina cinerea, Thanatus formicinus, Trachyzelotes pedestris, Trochosa hispanica, Titanoeca spominima, Ozyptila praticola and Zelotes electus in these wet habitats and sometimes in quite high abundance, are the first signal of water loss. It is known that the hydrology of the Subotica Sandland is changing rapidly (INPs 2003). The composition of the spider community at these habitats shows that as soon as the environment becomes drier, xerothermophilic species will invade and probably out-compete the typical hygrophilic species. The result would be a significant loss of all kind of invertebrate diversity. We suggest that these changes should be carefully observed and that the water regime should be directed in a way to take care of the hygrophilic species some of which are rare and/or even the only records for Serbia.

The dry habitats were characterised by a high number of xerothermophilic species of the family Gnaphosidae, and this strongly indicates an entirely different ecological entity. The numerous Drassyllus villicus, D. praeficus, Zelotes apricorum, Z. erebeus and Z. electus as typical dry meadow species (HängGi et al. 1995) together with the sandy species Titanoeca spominima and Berlandina cinerea indicate that Locality 1 (especially habitat M1) has adequate sunny and dry characteristics. This is supported by data for the species Gnaphosa 
mongolica which is very numerous at sandy meadows in Hungary (SzITA et al. 2005). These specific "Mediterranean-like" conditions (CнатZaki 2008) where thermophilic species like Oxyopes heterophthalmus, Bromella falcigera, Carrhotus xanthogramma can be found, seem to be a direct result of the implementation of clear-cutting measures that began in 2008 intending to preserve the indigenous sandy steppe vegetation. Although there are no data on spider fauna before 2008, it can be clearly seen that species composition is different from other habitats and thus can be positively related to these measures.

The habitats M1 and M2, both open meadows but with very different humidity conditions, show the highest diversity values. According to MaGURRAN (2004), usually, the Shannon indexes in ecological studies are between 1.5-3.5, rarely reaching 4, so these high values for $\mathrm{H}^{\prime}$ (3.60 M1 and 3.58 M2) are exceptional and show the importance of the open habitats in the study site Subotica Sandland. Relatively high values of $\mathrm{H}^{\prime}, \mathrm{E}$ and 1-D indexes were also found in the habitats M3, F, W5 and W6, indicating that these habitats are of particular importance considering nature (biodiversity) protection. In contrast, the woody, dry habitats W4, W3, W1 and W2 have lower values of $\mathrm{H}^{\prime}, \mathrm{E}$ and 1-D indexes. The reason could be the fact that those are not large forest areas, but only small patches of young woodland that are not (yet) well structured. Species that dominate here are clearly different from the species that dominate the open sandy meadow M1 and therefore contribute a lot to the overall diversity of the whole study site. These habitats actually show, what will happen in the near future if M1 becomes overgrown by hawthorn bushes. Species adapted to the sandy, rather steppe-like conditions will disappear, and forest species will emerge. According to all the above, M1, M2 and M3 should be priority habitats from a conservation point of view, and W6, W5 and $\mathrm{F}$ should be evaluated as important habitats too. However, the habitats W4, W3, W1 and W2 should not be considered very important.

From a conservation point of view, we prioritised the habitats as follows: M1, M2, M3, F, W5 and W6. This corresponds fully with conclusions made earlier about their quality (INPs 2003) based on other groups of organisms (plants, birds and amphibians).

According to the study (INPs 2003), Localities 2 and 3 with habitats M2, M3, F, W5 and W6, are areas under Level I of the protection regime, and our study confirms their significance. However, according to our study, some additional conservation measures could help substantially to preserve the unique fauna of all small invertebrates, not only spiders. For example, the corridors left behind as re-colonisation sites after mowing are approximately $50 \mathrm{~cm}$ wide. Although mowing is very beneficial for the spider fauna (Pozzi et al. 1998, Pozzi \& Borcard 2001, Szmatona-Turi \& Vona-Turi 2016) these corridors should be wider and not less than $1 \mathrm{~m}$. The actions to improve the 
hydrological regime of the area and stopping illegal melioration should be more intensive because many species depend on wet conditions, and the spider fauna already indicates the first signs of disturbance.

Since most investigations on spiders, (as with this one) are time-consuming and costly, we would like to suggest a different approach for conservation management measures. There is the possibility to select some umbrella species that are easier to monitor. For the wet habitats, we suggest Dolomedes plantarius, quite large and easy to find. Besides, the species has an impressive appearance and could also be used as flagship species. The flagship species or an umbrella species, in general, will be recognised by law on Nature Protection ("OfFicial Gazette of RS", No. 36/2009, 88/2010, 91/2010-ed., 14/2016 and 95/2018 - Act). In this way a large number of other species in the same habitats, which are less known and otherwise difficult to document, will be monitored too.

Locality 1 is under Level II of the protection regime. According to our spider study, habitat M1 (meadow steppe) is very important, with typical xerothermophilic species. A lot of these species are adapted to sandy soil and so demonstrate the speciality of the nature protection reserve at Subotica Sandland. We think that this important site should be in the Level I category of the protection regime. However, since this could be legally very difficult and time-consuming, the pending situation could be more damaging than helpful. Therefore, we recommend some additional measures that could be applied at the level of the company that manages the area. For example, clear-cutting should be a mandatory measure for the locality. The revitalisation of the sandsteppe habitat should continue to be a priority over the cultivation of forest habitats. Furthermore, we would suggest that the surface of the open sandy area should be enlarged, for example, by the part of the habitat W2 that has been identified as least valuable concerning spiders. Additionally, following the same proposal as for Localities 2 and 3, we would suggest Argiope lobata as umbrella species and once again also potential flagship species for this xerothermic habitat, in order to monitor the ecological development of the place.

Acknowledgements - This project was supported by The Provincial Secretariat for Science and Technological Development, of the Autonomous Province of Vojvodina. Grant \# 114-451-3881/2013-02. The authors would like to express gratitude to: Szekeres Otto, Sandra Čokić Reh and the whole ranger service of the Public company "Palic-Ludas" for valuable information and field support. Many thanks to the field team: Igor Gajić, Slavica Vaselek, Mima Filipendin, Srdjan Milosević, Snežana Štrbac, Milan Krsmanović and Snežana Stević for their great help of collecting and sorting material. We also thank Janet Beccaloni (England) for linguistic improvements. GG also expresses gratitude to professor Nataša Žugić, who encouraged her to start with this project as her PhD thesis. Many thanks, also, to the anonymous reviewers for their helpful comments. 


\section{REFERENCES}

Aakra, K., Morka, G. H., Antonson, A., Farlund, M., Wrånes. R. E., Frølandshagen, R., Løvbrekke, H., Furuseth, P., Fjellberg, A., Lemke, M., Pfliegler, W. P., Andersen, S., Olsen K. M., Aadland, B. \& Berggren, K. (2016): Spiders new to Norway (Arachnida, Araneae) with ecological, taxonomical and faunistic comments. - Norwegian Journal of Entomology 63(1): 6-43.

Almquist, S. (2006): Swedish Araneae, part 2 - families Dictynidae to Salticidae. - Insect Systematics \& Evolution, Supplement 63: 285-601.

Bali, L., Szinetár, Cs., Andrési, D.,TubA, K. \& Kálmán, K. (2017): Talajcsapdás arachnológiai vizsgálat az ásotthalmi Tanulmányi-erdőben. Pitfall trapping arachnological survey in the educational forest of Ásotthalom. - Erdészettudományi Közlemények 7(1): 69-84. https://doi.org/10.17164/EK.2017.005

Balogh, J. I. \& LoksA, I. (1947): Faunistische Angaben über die Spinnen des Karpatenbeckens. II. - Fragmenta Faunistica Hungarica 10: 61-68.

Blagoev, G., Deltshev, C., Lazarov, S. \& Naumova, M. (2018): The spiders (Araneae) of Bulgaria. Version: August 2018. - National Museum of Natural History, Bulgarian Academy of Sciences. Online at http://www.nmnhs.com/spiders-bulgaria/ [accessed on 10.9.2019]

BLIck, T. (1999): Spinnentiere. Pp. 147-160. In: Handbuch landschafts-ökologischer Leistungen - Empfehlungen zur aufwandsbezogenen Honorarermittlung. Selbstverlag der VUBD Vereinigung umweltwissenschaftlicher Berufsverbände, Deutschlands e.V. (Hrsg.). Nürnberg.

Blick, T. \& Szinetár, C. (1996): Glyphesis conicus ist ein jüngeres Synonym von Glyphesis taoplesius (Araneae: Linyphiidae). - Arachnologische Mitteilungen 11: 39-42. https:// doi.org/10.5431/aramit1105

Blick, T., Finch, O-D., Harms, K. H., Kiechle, J., Kielhorn, K-H., Kreuels, M., Malten, A., Martin, D., Muster, C., Nahrig, D., Platen, R., Rodel, I., Scheidler, M., Staudt, A., Stumpf, H. \& Tolke, D. (2016): Rote Liste und Gesamtartenliste der Spinnen (Arachnida: Araneae) Deutschlands. - In: Gruttke, H., Binot-Hafke, M., Balzer, S., Haupt, H., Hofbauer, N., Ludwig, G., Matzke-Hajek, G. \& Ries, M. (eds): Rote Liste gefährdeter Tiere, Pflanzen und Pilze Deutschlands, Band 4: Wirbellose Tiere (Teil 2). Münster (Landwirtschaftsverlag) - Naturschutz und Biologische Vielfalt 70 (4): 383-510.

Bosmans, R., Kherbouche-Abrous, O., Benhalima, S. \& Hervé, C. (2018): The genus Haplodrassus Chamberlin, 1922 in the Mediterranean and the Maghreb in particular (Araneae: Gnaphosidae). - Zootaxa 4451(1): 1-67. https://doi.org/10.11646/zootaxa.4451.1.1

Breitling, R. (2019): A barcode-based phylogenetic scaffold for Xysticus and its relatives (Araneae: Thomisidae: Coriarachnini). - Ecologica Montenegrina 20: 198-206. https:// doi.org/10.5431/aramit5010

Breitling, R., Lemke, M., Bauer, T., Hohner, M., Grabolle, A. \& Blick, T. (2015): Phantom spiders: notes on dubious spider species from Europe. - Arachnologische Mitteilungen 50: 65-80. https://doi.org/10.5431/aramit5010

BresjančEva, J. (1907): Prilog za poznavanje srpske aranijske faune. - Radovi iz Zoološkog Instituta u Univerzitetu 1(2-3): 1-16. [in Serbian]

Caro, T., Engilis, Jr. A., Fitzherbert, E. \& Gardner, T. (2004): Preliminary assessment of the flagship species concept at a small scale. - Animal Conservation 7: 63-70. https:// doi.org/10.1017/S136794300300115X

Chatzaki, M. (2008): A critical review of the spider family Gnaphosidae in Greece. Advances in Arachnology and Developmental Biology. Pp. 355-374. In: MaKarov, S. E. \& 
Dimitrijević, R. N. (eds): Papers dedicated to Prof. Dr. Božidar Ćurčić. Monographs 12. Inst. Zool., Belgrade; BAS, Sofia; Fac. Life Sci., Vienna; SASA, Belgrade \& UNESCO MAB Serbia. Vienna-Belgrade-Sofia.

Chyzer, C. \& Kulczyński, W. (1894): Araneae Hungariae. Tomus II. - Academia Scientarum Hungaricae, Budapest, 151 pp., pls 1-5.

Chyzer, C. \& Kulczyński, W. (1897): Araneae Hungariae. Tomus II. - Academia Scientarum Hungaricae, Budapest. pp. 147-366, pls 6-10.

Clausen, I. H. S. (1986): The use of the spiders (Araneae) as ecological indicators. - Bulletin of the British Arachnological Society 7: 83-86.

Ćurčıć, B. P. M., Deltshev, C. C., Tomić, V. T. \& Ćurčıć, S. B. (2007): Biodiversity of spiders: on some taxa new to Serbia and to science. Belgrade. - Archives of Biological Sciences 59(2): 19-20. https://doi.org/10.2298/ABS070219PC

Dawson, I. K. (2011): Clubiona rosserae at Chippenham Fen. - Newsletter of the British Arachnological Society 120: 21-24.

Déjean, S. (2012): Découverte en France de Theridion uhligi Martin, 1974 (Araneae, Theridiidae). - Bulletin Mensuel de la Société Linnéenne de Lyon 81: 265-269. https://doi. org/10.3406/linly.2012.13837

Deltshev, C., Ćurčić, B. \& Blagoev, G. (2003): The spiders of Serbia. - Institute of Zoology, Faculty of Biology, University of Belgrade, Belgrade, 833 pp.

Dondale, C. D. \& Redner, J. H. (1975): The genus Ozyptila in North America (Araneida, Thomisidae). - Journal of Arachnology 2: 129-181.

Drensky, P. (1943): Die Spinnenfauna Bulgariens. VI. Unterordnung Arachnomorphae, II Gruppe Trionichia, Familie Euetrioidae. - Bulletin des Institutions Royales d'Histoire Naturelle à Sophia 16: 219-254.

Dudić, B. D., Tomić, V. T., Sivčev, I., Buchs, W., Sivčev, L., Graora, D. \& Gotuin-Čuljak, T. (2013): New data on spider fauna from northern Serbia. - Archives of Biological Sciences 65(4): 1669-1673. https://doi.org/10.2298/ABS1304669D

Duma, I. (2008): Theridion uhligi Martin, 1974 (Araneae: Theridiidae) new to Romania. Entomologica Romanica 13: 297-299.

Duma, I. (2009): New data on Theridion italiense, with description of the unknown female. - Journal of Arachnology 37: 383-387. https://doi.org/10.1636/A08-91.1

Dumpert, K. \& Platen, R. (1985): Zur Biologie eines Buchenwaldbodens. 4. Die Spinnenfauna. - Carolinea 42: 75-106.

El-Hennawy, H. K., Mohafez, M. A., El-Gendy, A. A. \& Zaher, I. A. I. (2016): The first record of Ostearius melanopygius (O. Pickard-Cambridge, 1879) and genus Ostearius Hull, 1911 (Araneae: Linyphiidae) in Egypt. - Serket 15(1): 63-67.

ÉneKesová, E., ŠEstákovÁ, A. \& KRUmpálovÁ, Z. (2011): A first record of Glyphesis taoplesius (Linyphiidae, Araneae) from Slovakia. - Arachnologische Mitteilungen 42: 16-20. https://doi.org/10.5431/aramit4204

FINCH, O. D. (2008): Webspinnen, Weberknechte und Pseudoskorpione der Ostfriesischen Inseln. - Schriftenreihe Nationalpark Niedersächsisches Wattenmeer 11(S): 103-112.

Foelix, R. F. (1996): Biology of spiders. 2nd ed. - Oxford University Press, New York, 330 pp.

Frick, H. \& StaręGA, W. (2009): Hypsocephalus dahli is a junior synonym of Microneta pusilla (Araneae, Linyphiidae). - Arachnologische Mitteilungen 37:12-14. https://doi. org/10.5431/aramit3703

Frick, H. (2008): First record of Hypsocephalus dahli in Switzerland with a review of its distribution, ecology and taxonomy (Araneae, Linyphiidae). - Arachnologische Mitteilungen 35: 35-44. https://doi.org/10.5431/aramit3505 
Funushima, C., Mendoza, J. I., West, R. C., Longhorn, S. J., Rivera, E., Cooper, E. W. T., Hénaut, Y., Henriques, S. \& Cardoso, P. (2019): Species conservation profiles of tarantula spiders (Araneae, Theraphosidae) listed on CITES. - Biodiversity Data Journal 7: e39342. https://doi.org/10.3897/BDJ.7.e39342

Gajdoš, P. \& Svanton, S. (1993): The red list of spiders of Slovakia. - Bullettino delle sedute della Accademia Gioenia di scienze naturali in Catania 26 (345): 115-133.

Gajdoš, P., ČERnecká, L'. \& ŠEstáKová, A. (2019): Pannonic salt marshes revealed six new spiders to Slovakia (Araneae: Gnaphosidae, Linyphiidae, Lycosidae, Theridiidae). Biologia (Bratislava) 74(1): 53-64. https://doi.org/10.2478/s11756-018-0145-z

Gajić, I. \& Grbić, G. (2016): Faunistic research on spiders (Arachnida, Araneae) in the Special Nature Reserve 'Zasavica', Serbia. - Arachnologische Mitteilungen 51: 49-56. https://doi.org/10.5431/aramit5107

Gnelitsa, V. A. (2009): A survey of Crimean Linyphiidae (Aranei). 1. On seven rare and little known linyphiids from Crimea. - Arthropoda Selecta 17: 191-202.

Gnelitsa, V. A. (2012): The genus Sintula (Aranei, Linyphiidae) in Ukraine, with the description of a new species. - Vestnik Zoologii 46: 29-36. https://doi.org/10.2478/v10058012-0003-3

Grbić, G. \& Savić, D. (2010): Contribution to the knowledge of the spider fauna (Arachnida, Araneae) on the Fruška Gora Mt. - Acta Entomologica Serbica 15(2): 243-260.

Grbić, G., Gajić, I. \& Stanković, M. (2011): Preliminary notes on the spider fauna (Arachnida, Araneae) of the Special Nature Reserve Zasavica. - Acta Entomologica Serbica 16(1-2): 127-138.

Grbić, G., HäNGgi, A. \& SAvić, D. (2015): New faunistic records of spiders (Arachnida, Areneae) from the Fruška Gora Mt., North Serbia. - Acta Zoologica Bulgarica 67(3): 479-86.

Grbić, G., HängGi, A., Gajić, I., VAselek, S. \& Ivković, S. (2019): Spiders (Araneae) living in the Deliblato Sands (Serbia) the largest European continental sands. - Acta Entomologica Serbica 24(1): 79-93. https://doi.org/10.5281/zenodo.3249916

Gregorič, M. \& Kuntner, M. (2009): Epigean spider diversity in the classical karst. - Hacquetia 8: 67-78. https://doi.org/10.2478/v10028-009-0005-z

Grimm, U. (1985): Die Gnaphosidae Mitteleuropas (Arachnida, Araneae). - Abhandlungen des Naturwissenschaftlichen Vereins in Hamburg (NF) 26: 1-318.

HängGI, A. (1990): Beiträge zur Kenntniss der Spinnenfauna des Kt. Tessin III - für die Schweiz neue und bemerkenswerte Spinnen (Arachnida: Araneae). - Mitteilungen der Schweizerischen entomologischen Gesellschaft 63:153-167. https://doi.org/10.5169/seals-402384

Hänggi, A., Stöckli, E. \& Nentwig, W. (1995): Habitats of Central European spiders - Characterization of the habitats of the most abundant spider species of Central Europe and associated species. - Schweizerisches Zentrum für die kartographische Erfassung der Fauna (SZKF), Neuchâtel, 460 pp.

Harm, M. (1977): Revision der mitteleuropäischen Arten der Gattung Phlegra Simon (Arach.: Araneae: Salticidae). - Senckenbergiana Biologica 58: 63-77.

Harvey, P., Davidson, M., Dawson, I., Fowles, A., Hitchcock, G., Lee, P., Merrett, P., Russell-Smith, A. \& Sмiтh, H. (2017): A review of the scarce and threatened spiders (Araneae) of Great Britain: Species Status No. 22. NRW Evidence Report No. 11. - Natural Resources Wales, Bangor, 101 pp.

Heimer, S. \& Nentwig, W. (1991): Spinnen Mitteleuropas: Ein Bestimmungsbuch. - Paul Parey, Berlin, 543 pp.

Helsdingen, P. J. van (1982): Eperigone trilobata revealed as a trans-American species. Bulletin of the British Arachnological Society 5: 393-396. 
Helsdingen, van P.J., IJland, S. (2007): Mermessus species in the Netherlands (Araneae, Linyphiidae). - Nieuwsbrief SPINED 23:27-29.

Hippa, H. \& Mannila, R. (1982): Pardosa maisa sp. n. (Araneae, Lycosidae) from northern Europe. - Bulletin of the British Arachnological Society 5(9): 420-422.

Hirna, A. (2017): First record of the alien spider species Mermessus trilobatus (Araneae: Linyphiidae) in Ukraine. - Arachnologische Mitteilungen 54: 41-43. https://doi. org/10.5431/aramit5409

Hyvärinen, E., Juslén, A., Kemppainen, E., Uddström, A. \& Liukko, U-M. (eds) (2019): The 2019 Red list of Finnish species. - Ympäristöministeriö \& Suomen ympäristökeskus, Helsinki, 704 pp.

INPS (2003): Predeo izuzetnih odlika Subotička peščara, predlog za stavlajnje pod zaštitu kao prirodnog dobra od velikog značaja. - Zavod za zaštitu prirode Srbije, Novi Sad, 221 pp.

IUCN (2019): Red list of threatened species. World Conservation Monitoring Centre 1996. Dolomedes plantarius. The IUCN Red List of Threatened Species [Internet]. 1996 [accessed on 21.02.2019]. https://doi.org/10.2305/IUCN.UK.1996.RLTS.T6790A12806270.en

Jocqué, R. (1977): Contribution à la connaissance des araignées de Belgique, V. Description de Theridion hublei n. sp. - Revue Arachnologique 1: 59-63.

Kancsal B., Szinetár, C., Bognár, V. \& Angyal, D. (2010): Data to the spider fauna (Araneae) of Lake Velence. - Natura Somogyiensis 17: 133-140.

Kastrygina, Z. A. \& Kovblyuk, M. M. (2014): The spider genus Pulchellodromus Wunderlich, 2012 in the Crimea (Aranei: Philodromidae). - Arthropoda Selecta 23(3): 279-283. https://doi.org/10.15298/arthsel.23.3.07

Kerekes, J. (1988): Faunistic studies on epigeic spider community on sandy grassland (KNP). - Acta Biologica Szegediensis 34: 113-117.

Komnenov, M. \& Pavićević, D. (2008): New data on spider fauna (Araneae) of the city of Belgrade (Part I). - Zaštita prirode 60(1-2): 189-194.

Komnenov, M. (2014): Spider fauna of the Osogovo Mt. Range, Northeastern Macedonia. - Fauna Balkana 2: 1-267.

Kovblyuk, M. M., Kastrygina, Z. A. \& Omelko, M. M. (2012): A review of the spider genus Haplodrassus Chamberlin, 1922 in Crimea (Ukraine) and adjacent areas (Araneae, Gnaphosidae). - ZooKeys 205: 59-89. https://doi.org/10.3897/zookeys.205.3491

KulCZYŃsKI, W. (1898): Symbola ad faunam aranearum Austriae inferioris cognoscendam. - Rozprawy i Sprawozdania z Posiedzen Wydzialu Matematyczno Przyrodniczego Akademji Umiejetnosci, Krakow 36: 1-114.

Kůrka, A., Naumova, M., Indzhov, S. \& Deltshev, C. (2020): New faunistic and taxonomic data on the spider fauna of Albania (Arachnida: Araneae). - Arachnologische Mitteilungen 59: 8-21. https://doi.org/10.30963/aramit5903

Kuzmin, E. A. \& Esyunin, S. L. (2016): The dictynid spider fauna (Aranei) of Ulyanovsk Region (Russia). - Caucasian Entomological Bulletin 12(1): 29-34.

Levy, G. (1984): The spider genera Singa and Hypsosinga (Araneae, Araneidae) in Israel. - Zoologica Scripta 13(2): 121-133. https://doi.org/10.1111/j.1463-6409.1984.tb00029.x

Levy, G. (1991): On some new and uncommon spiders from Israel (Araneae). - Bulletin of the British Arachnological Society 8: 227-232.

Locket, G. H. \& Millidge, A. F. (1951): British spiders. Vol. I. - Ray Society, London, 310 pp.

Logunov, D. V. (1996): A critical review of the spider genera Apollophanes O. P.-Cambridge, 1898 and Thanatus C. L. Koch, 1837 in North Asia (Araneae, Philodromidae). - Revue Arachnologique 11: 133-202.

Loksa, I. (1969): Pókok I - Araneae I. Fauna Hungariae - Akadémiai Kiadó, Budapest, 133 pp. 
Loksa, I. (1972): Pókok II - Araneae II. Fauna Hungariae - Akadémiai Kiadó, Budapest, 112 pp.

LoksA, I. (1981): Die Bodenspinnen zweier Torfmoore im Oberen Theiss-Gebiet Ungarns. Opuscula Zoologica, Budapest 17-18: 91-106.

LoKsA, I. (1987): The spider fauna of the Kiskunság National Park (Araneae). Pp. 335-342. In: Manunka, S. (ed.): The fauna of the Kiskunság National Park. Akadémiai Kiadó, Budapest.

Maelfait, J-P. \& HendRICKX, F. (1998): Spiders as bioindicators of anthropogenic stress in natural and semi-natural habitats in Flanders (Belgium): some recent developments. Pp. 293-300. In: Selden, P. A. (ed.): Proceedings of the 17th European Colloquium of Arachnology. - Dorset Press, Edinburgh.

Maelfait, J-P., Baert, L., Bonte, D., de BakKer, D., Gurdebeke, S. \& Hendrickx, F. (2003): The use of spiders as indicators of habitat quality and anthropogenic disturbance in Flanders, Belgium. Pp. 129-141. In: Samu, F. \& Szinetár, C. (eds): European Arachnology 2002. - Proceedings of the 20th European Colloquium of Arachnology. Szombathely, Hungary.

Magurran, A. E. (2004): Measuring biological diversity. - Blackwell Publishing, Oxford, 260 pp.

Martin, D. (1974): Theridium uhligi nov. spec., eine bisher unbekannte Kugelspinne (Araneae: Theridiidae). - Deutsche Entomologische Zeitschrift (N.F.) 22: 113-115.

Marusik, Y. M. \& Logunov, D. V. (1995): Gnaphosid spiders from Tuva and adjacent territories, Russia. - Beiträge zur Araneologie 4(1994): 177-210.

Marusik, Y. M., Esyunin, S. L. \& Tuneva, T. K. (2015): A survey of Palaearctic Dictynidae (Araneae). 1. Taxonomic notes on Dictynomorpha Spassky, 1939, Brigittea Lehtinen, 1967 and Lathys Simon, 1884. - Zootaxa 3925(1): 129-144. https://oi.org/10.11646/ zootaxa.3925.1.9

Metzner, H. (1999): Die Springspinnen (Araneae, Salticidae) Griechenlands. - Andrias 14: $1-279$.

Mezófr, L. \& Markó, V. (2018): Some rare and remarkable spider species from Hungary (Arachnida: Araneae). - Arachnologische Mitteilungen 55: 1-9. https://doi.org/10.30963/ aramit5501

MilasowszKY, N. \& ZulKa, K. P. (1998): Habitat requirements and conservation of the 'flagship species' Lycosa singoriensis (Laxmann 1770) (Araneae: Lycosidae) in the National Park Neusiedler See-Seewinkel (Austria). - Zeitschrift für Ökologie und Naturschutz 7: 111-119.

Miller, F. \& Buchar, J. (1977): Neue Spinnenarten aus der Gattung Zelotes Distel [sic] und Haplodrassus Chamberlin (Araneae, Gnaphosidae). - Acta Universitatis Carolinae Biologica (Biol.) 1974: 157-171.

Miller, F. (1947): Pavoučí zvířena hadcových stepí u Mohelna. - Archiv Svazu na Výzkum a Ochranu Př́rody i Krajiny v Zemi Moravskoslezské 7: 1-107.

Miller, F. (1966): Einige neue oder unvollkommen bekannte Zwergspinnen (Micryphantidae) aus der Tschechoslowakei (Araneidea). - Acta Entomologica Bohemoslovaca 63:149-164.

Miller, F. (1968): Sintula buchari sp. n., eine neue Zwergspinne aus der Tschechoslowakei (Araneidea, Micryphantidae). - Acta Entomologica Bohemoslovaca 65: 241-245.

Miller, F. (1971): Pavouci-Araneida. - Klić zvířeny CSSR 4: 51-306.

Millidge, A. F. (1978): The genera Mecopisthes Simon and Hypsocephalus n. gen. and their phylogenetic relationships (Araneae: Linyphiidae). - Bulletin of the British Arachnological Society 4: 113-123. 
Muster, C. \& Thaler, K. (2003): The Thanatus striatus species group in the eastern Alps, with description of Thanatus firmetorum sp. n. (Araneae: Philodromidae). - Bulletin of the British Arachnological Society 12: 376-382.

Muster, C., Bosmans, R. \& Thaler, K. (2007): The Philodromus pulchellus-group in the Mediterranean: taxonomic revision, phylogenetic analysis and biogeography (Araneae: Philodromidae). - Invertebrate Systematics 21: 39-72. https://doi.org/10.1071/IS06014

Naumova, M., Blagoev, G., Dimitrov, D., Lazarov, S. \& Deltshev, C. (2017): New data on the spider fauna (Arachnida: Araneae) of Bulgaria. - Acta Zoologica Bulgarica 69(4): 477-481.

Naumova, M., Lazarov, S. \& Deltshev, C. (2019): Faunistic diversity of the spiders in Montenegro (Arachnida: Araneae). - Ecologica Montenegrina 22: 50-89. https://doi. org/10.37828/em.2019.22.5

NeEt, C. R. (1996): Spiders as indicator species: lessons from two case studies. Pp. 501-510. In: Mahnert, V. (ed.): Proceedings of the XIIIth International Congress of Arachnology. Geneva. 1995. - Revue suisse de zoologie. Vol. hors série I, Genéve.

Nentwig, W., Blick, T., Bosmans, R, Gloor, D., Hänggi, A. \& Kropf, C. (2020): Araneae - spiders of Europe. Version 09.2020. https://www.araneae.nmbe.ch [accessed on 05.09.2020] https://doi.org/10.24436/1

Nikolić, F. \& Polenec, A. (1981): Catalogus faunae Jugoslaviae - Aranea. - Slovenska Akademija znanosti in Umetnosti, Ljubljana, $135 \mathrm{pp}$.

Official Gazette of Republic of Serbia, No. 36/2009, 88/2010, 91/2010-ed., 14/2016, 95/2018-Act. Law on Nature Protection. [in Serbian]

Official Gazette of RS, no. 5/2010, 47/2011, 32/2016, 98/2016. Code on declaration and protection of strictly protected and protected wild species of plants, animals and fungi. [in Serbian].

Official Gazette of RS, no. 66/91, 127/2003, 113/2004. Regulation on the conservation of The Subotica Sandland, as the landscape of outstanding feature. [in Serbian].

Oger, P. \& Picard, J. (2014): Découverte en France de Mermessus denticulatus (Banks, 1898) (Araneae, Linyphiidae). - Revue Arachnologique 2 (1): 2-4.

Oleszczuk, M., Hajdamowicz, I. \& Stańska, M. (2011): The distribution and habitat preferences of an extremely rare European spider, Glyphesis taoplesius (Araneae, Linyphiidae). - Entomologica Fennica 22: 15-20. https://doi.org/10.33338/ef.4240

Ovtsharenko, V. I., Platnick, N. I. \& Song, D. X. (1992): A review of the North Asian ground spiders of the genus Gnaphosa (Araneae, Gnaphosidae). - Bulletin of the American Museum of Natural History 212: 1-88.

Paquin, P. \& Dupérré, N. (2003): Guide d'identification des araignées de Québec. - Fabreries, Supplement 11: 1-251.

Polchaninova, N. Yu., Gnelitsa, V. A., Evtushenko, K. V. \& Singaevsky, E. N. (2017): An annotated checklist of spiders (Arachnida: Aranei) of the National Nature Park ‘Buzkyi Hard' (Mykolaiv Area, Ukraine). - Arthropoda Selecta 26: 253-272. https://doi. org/10.15298/arthsel.26.3.08

Polenec, A. \& Thaler, K. (1980): Zwei wenig bekannte Deckennetzspinnen Südost-Europas: Centromerus vindobonensis Kulczynski und Leptyphantes istrianus Kulczynski (Arachnida: Araneae: Linyphiidae). - Senckenbergiana Biologica 61: 103-111.

Pozzi, S. \& Borcard, D. (2001): Effects of dry grassland management on spider (Arachnida: Araneae) communities on the Swiss occidental plateau. - Ecoscience 8(1): 32-44. https://doi.org/10.1080/11956860.2001.11682628

Pozzi, S. \& HäNGgI, A. (1998): Araignées nouvelle ou peu connues de la Suisse (Arachnida: Araneae). - Mitteilungen der schweizerischen entomologischen Gesellschaft 71: 33-47. 
Pozzi, S., Gonseth, Y. \& Hänggi, A. (1998): Evaluation of dry grassland management on the Swiss occidental plateau using spider communities (Arachnida: Araneae). - Revue suisse de zoologie 105(3): 465-485. https://doi.org/10.5962/bhl.part.80046

К̌neź́č, M., Kůrka, A., RůžičKA, V. \& Heneberg, P. (2015): Red List of Czech spiders. 3rd edition, adjusted according to evidence-based national conservation priorities. - Biologia 70(5): 645-666. https://doi.org/10.1515/biolog-2015-0079

Roberts, M. J. (1985): The spiders of Great Britain and Ireland, Vol. 1: Atypidae to Theridiosomatidae. - Harley Books, Colchester, 229 pp.

Roberts, M. J. (1987): The spiders of Great Britain and Ireland, Volume 2: Linyphiidae and check list. - Harley Books, Colchester, 204 pp.

Roberts, M. J. (1998): Spinnengids. - Tirion, Baarn, Netherlands, 397 pp.

RozwaŁKa, R. \& Stachowicz, J. (2010): First record of Ostearius melanopygius (Cambridge, 1879) (Araneae: Linyphiidae) in the eastern part of Poland. - Przeglad Zoologiczny 52-43: 159-161.

RŮŽIČKA, V. (2018): A review of the spider genus Porrhomma (Araneae, Linyphiidae). Zootaxa 4481(1): 1-75. https://doi.org/10.11646/zootaxa.4481.1.1

Sattler, T., Pezzatti, B., Nobis, M. P., Овrist, M. K., Roth, T. \& Moretti, M. (2013): Selection of multiple umbrella species for functional and taxonomic diversity to represent urban biodiversity. - Conservation Biology 28(2): 414-426. https://doi.org/10.1111/cobi.12213

Šestáková, A., Suvák, M., Krajčovičová, K., Kaňuchová, A. \& Christophoryová, J. (2017): Arachnids from the greenhouses of the Botanical Garden of the PJ Šafárik University in Košice, Slovakia (Arachnida: Araneae, Opiliones, Palpigradi, Pseudoscorpiones). Arachnologische Mitteilungen 53: 19-28. https://doi.org/10.5431/aramit5304

Spasojević, M. (1891): Trochosa infernalis Moth, jedan interesantan pauk - trkač iz okoline Beograda, Śapca, Niša, Leskovca i Pirota. Beograd. - Nastavnik. 2(3): 202-218. [in Serbian]

Stojićević, D. (1929): Pravi pauci u Srbiji. Araneae Sund. Les araignees de Serbie. Skupio Dušan Stojićević, Muzej Srpske Zemlje. Beograd: Posebno izdanje. 19: 1-65. [in Serbian]

Svatoň, J., Gajdoš, P., Černecká, L., Franc, V., Korenko, S., Kovalčík, R. \& Krumpálová, Z. (2009): Pavúky - Araneae. Pp. 21-123. In: Mašán, P. \& MináL, I. (eds): Pavúkovce Cerovej Vrchoviny. Arachnids of the Cerová Vrchovina Highland (Arachnida: Araneae, Pseudoscorpiones, Opiliones, Acari), Institute of Forest Ecology, Zvolen.

Szinetár, C. \& Guitprecht, G. (2001): A Pardosa maisa Hippa \& Mannila, 1982 előkerülése Magyarországon (Araneae, Lycosidae). - Folia Musei Historico-Naturalis Bakonyiensis 17: 87-96.

Szinetár, C., Eichardt, J. \& SzüTs, T. (2009): The first lowland species of the Holarctic alpine ground spider genus Parasyrisca (Araneae, Gnaphosidae) from Hungary. ZooKeys 16: 197-208. https://doi.org/10.3897/zookeys.16.234

Szita, É. \& SAMU, F. (2000): Taxonomical review of Thanatus species (Philodromidae, Araneae) of Hungary. - Acta Zoologica Academiae Scientiarum Hungaricae 46: 155-179.

Szita, É., Samu, F., Szinetár, C., Dudás, G., Botos, E., Horváth, R. \& Szalkovski, O. (2005): New data on the occurrence of Gnaphosa rufula (L. Koch, 1866) and Gnaphosa mongolica Simon, 1895 in Hungary. Pp. 329-334. In: Deltshev, C. \& Stoev, P. (eds): European Arachnology 2005. - Acta Zoologica Bulgarica 57(Supplement 1).

Szmatona-Turi, T. \& VonA-Turi, D. (2016): The effect of grassland management on diversity of spider assemblages in the Mátra mountain. - Ecologica Montenegrina 7: 291297. https://doi.org/10.37828/em.2016.7.6 
Thaler, K. (1968): Zum Vorkommen von Porrhomma-Arten in Tirol und anderen Alpenländern (Arachn., Araneae, Linyphiidae). - Berichte des NaturwissenschaftlichMedizinischen Vereins in Innsbruck 56: 361-388.

Thaler, K. (1997): Tallusia pindos n.sp. aus N-Griechenland (Araneae, Linyphiidae). Linzer Biologische Beiträge 29: 377-384.

Tоміс́, V. \& Grbić, G. (2008): Preliminary notes on spider fauna of mt. Fruška Gora. Invertebrates (Invertebrata) of The Fruška Gora mountain, I. - Matica Srpska, Novi Sad, 57-64. pp.

Tullgren, A. (1944): Svensk Spindelfauna. 3. Araneae (Salticidae, Thomisidae, Philodromidae och Eusparassidae). - Entomologiska Föreningen, Stockholm, 138 pp., pls 1-18.

Tullgren, A. (1946): Svensk spindelfauna: 3. Egentliga spindlar. Araneae. Fam. 5-7. Clubionidae, Zoridae och Gnaphosidae. - Entomologiska Föreningen, Stockholm, 141 pp., pls 1-21.

Tuneva, T. K. \& Esyunin, S. L. (2002). A review of the family Gnaphosidae in the fauna of the Urals (Aranei), 2. New and rare genera. - Arthropoda Selecta 10(3)[2001]: 217-224.

Weiss, I. \& Petrișor, A. (1999): List of the spiders (Arachnida: Araneae) from Romania. Travaux du Muséum National d'Histoire Naturelle “Grigore Antipa” 41: 79-107.

Weiss, I. \& MARCU, A. (1988). Gnaphosa spinosa Kulczyński, eine unvollständig beschriebene Spinne Südosteuropas (Arachnida, Araneae, Gnaphosidae). - Reichenbachia 25: 113-115.

Weiss, I. (1979): Das Männchen von Phlegra m-nigra (Kulczynski, 1891), nebst Betrachtungen über Bau und Funktion der Kopulationsorgane mitteleuropäischer Arten der Gattung Phlegra s. 1. (Arachnida: Araneae: Salticidae). - Studii şi Comunicări Muzeul Brukenthal, Ştiin țe Naturale 23: 239-250.

WieHLe, H. (1953): Spinnentiere oder Arachnoidea (Araneae) IX: Orthognatha-CribellataeHaplogynae-Entelegynae (Pholcidae, Zodariidae, Oxyopidae, Mimetidae, Nesticidae). - Die Tierwelt Deutschlands 42: 1-150.

Wiehle, H. (1960): Spinnentiere oder Arachnoidea (Araneae). XI. Micryphantidae - Zwergspinnen. - Die Tierwelt Deutschlands 47: 1-620.

Wiehle, H. (1965): Die Clubiona-Arten Deutschlands, ihre natürliche Gruppierung und die Einheitlichkeit im Bau ihrer Vulva (Arach., Araneae). - Senckenbergiana Biologica 46: 471-505.

Wsc (2020): World Spider Catalog. Version 20.0. Natural History Museum Bern. http://wsc. nmbe.ch [accessed at 05.09.2020] https://doi.org/10.24436/2

Wunderlich, J. \& Schultz, W. (1995): Ozyptila westringi (Thorell, 1873), eine in Deutschland seltene Krabbenspinnenart (Arachnida: Araneae: Thomisidae). - Beiträge zur Araneologie 4[1994]: 329-333.

Wunderlich, J. (1969): Zur Spinnenfauna Deutschlands, IX. Beschreibung seltener oder bisher unbekannter Arten (Arachnida: Araneae). - Senckenbergiana Biologica 50: 381-393.

Wunderlich, J. (1972). Zur Kenntnis der Gattung Walckenaeria Blackwall, 1833 unter besonderer Berücksichtigung der europäischen Subgenera und Arten (Arachnida: Araneae: Linyphiiidae). - Zoologische Beiträge (N.F.) 18: 371-427.

Wunderlich, J. (1992): Eine bisher unbekannte Spinnen-Art der Gattung Syedra Simon aus Europa (Arachnida: Araneae: Linyphiidae). - Entomologische Zeitschrift 102: 280-285.

Wunderlich, J. (1993): Beschreibung einer bisher unbekannten Spinnenart der Gattung Titanoeca Thorell aus Deutschland (Arachnida: Araneae: Titanoecidae). - Entomologische Zeitschrift 103: 347-351.

Zamani, A. \& Marusik, Y. M. (2017): Six new species of spiders (Arachnida: Araneae) from Iran. - Oriental Insects 51(4): 313-329. https://doi.org/10.1080/00305316.2017.1282386

Received June 30, 2020, accepted December 5, 2020, published February 22, 2021 


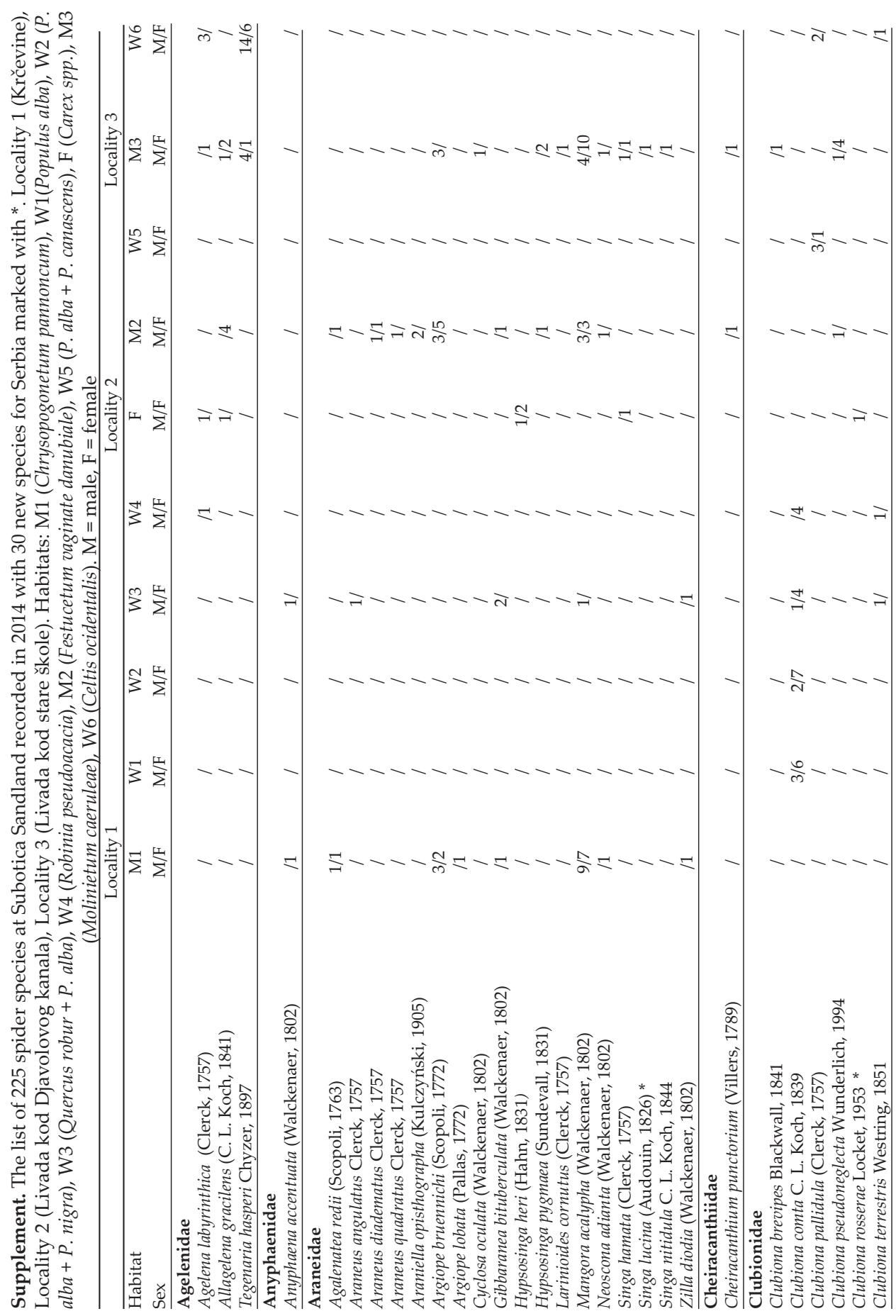




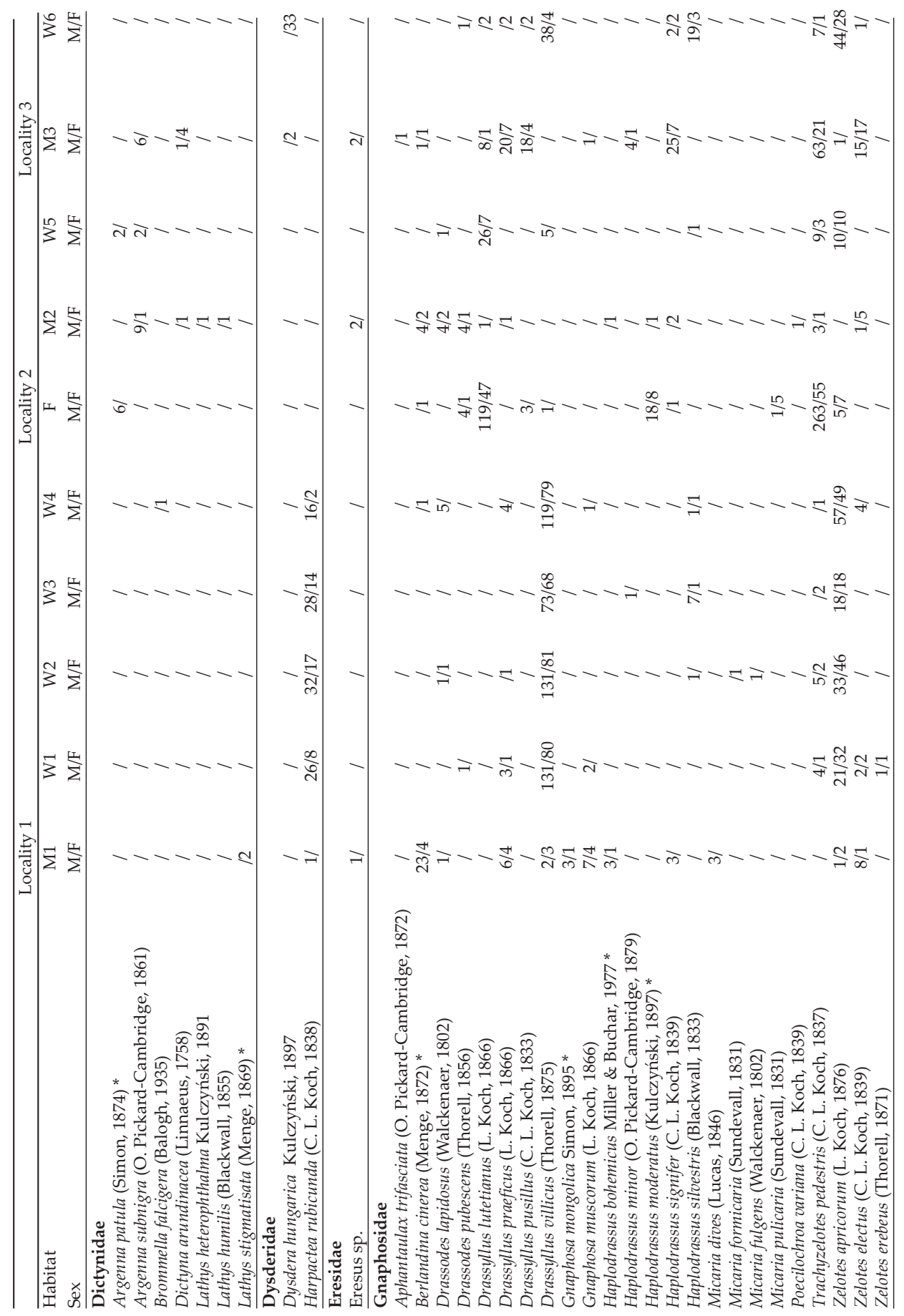




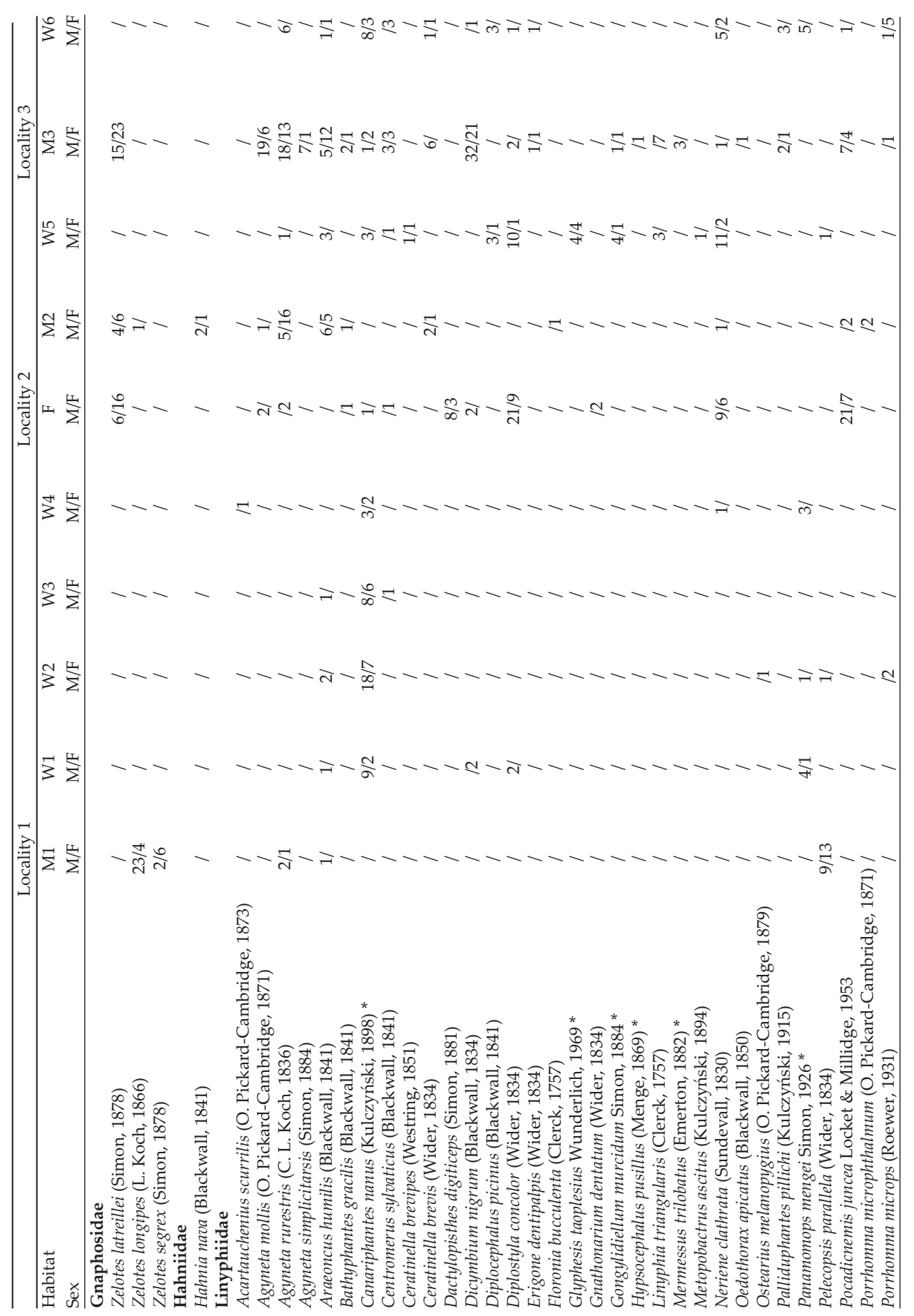




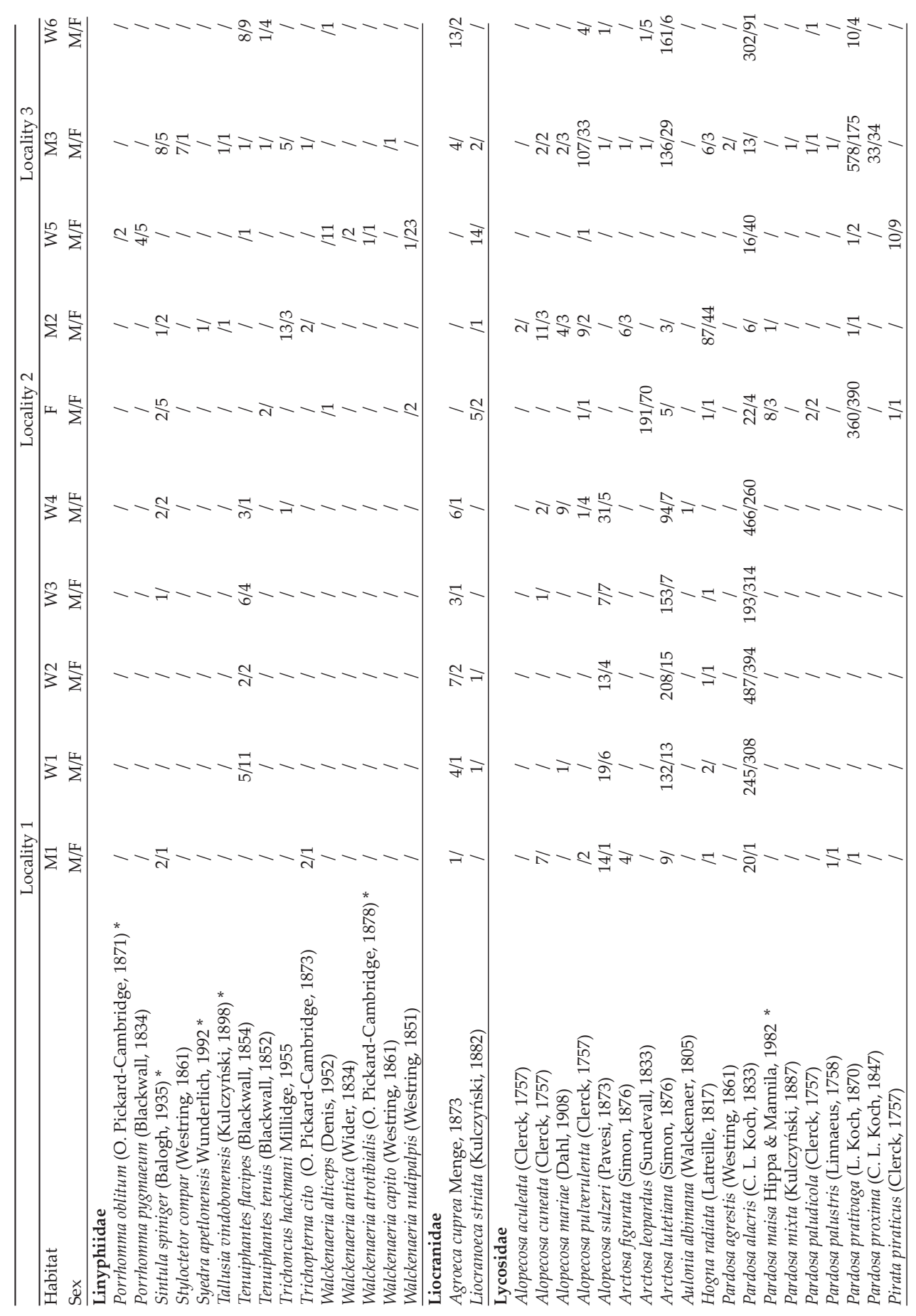




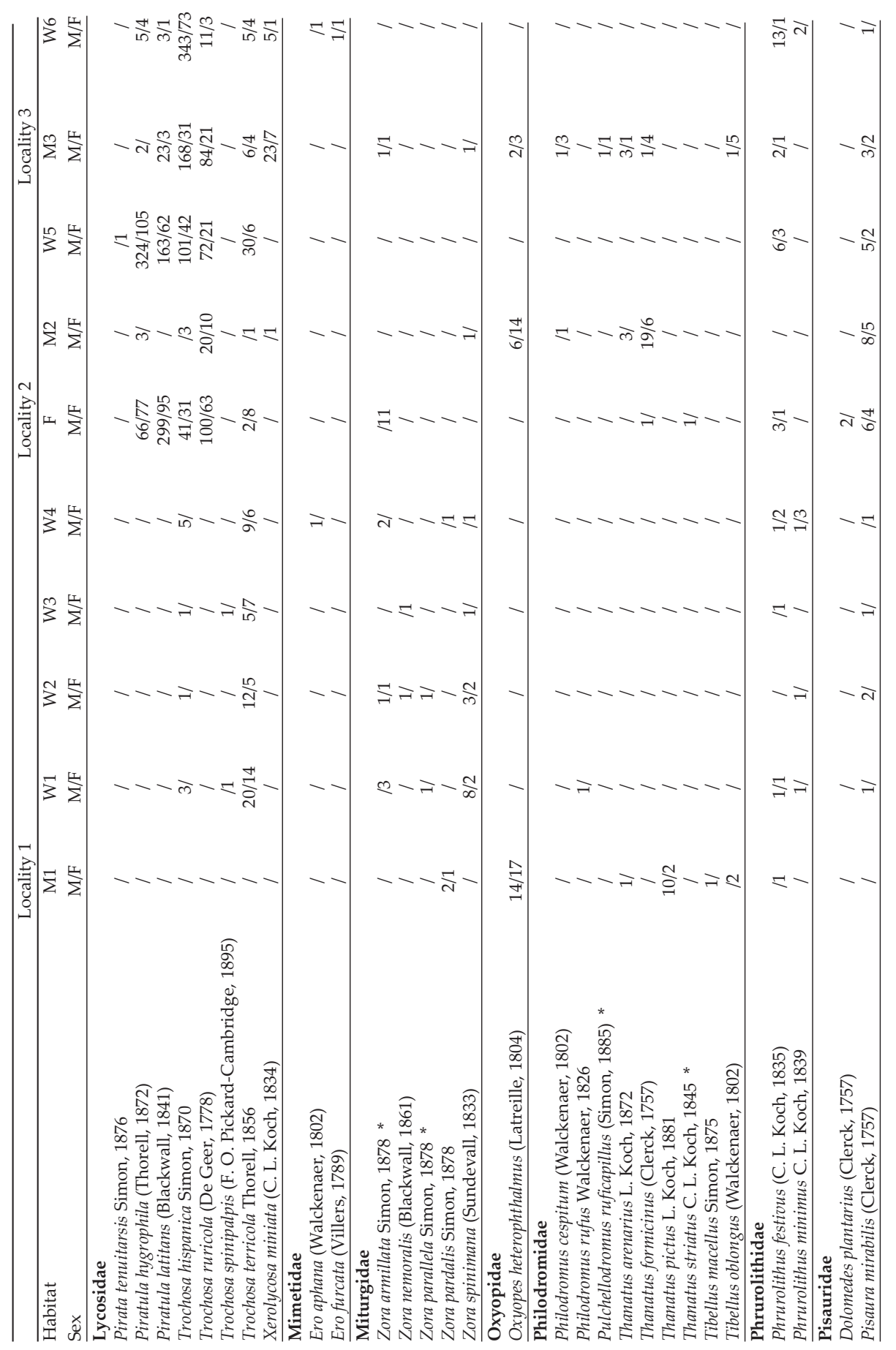




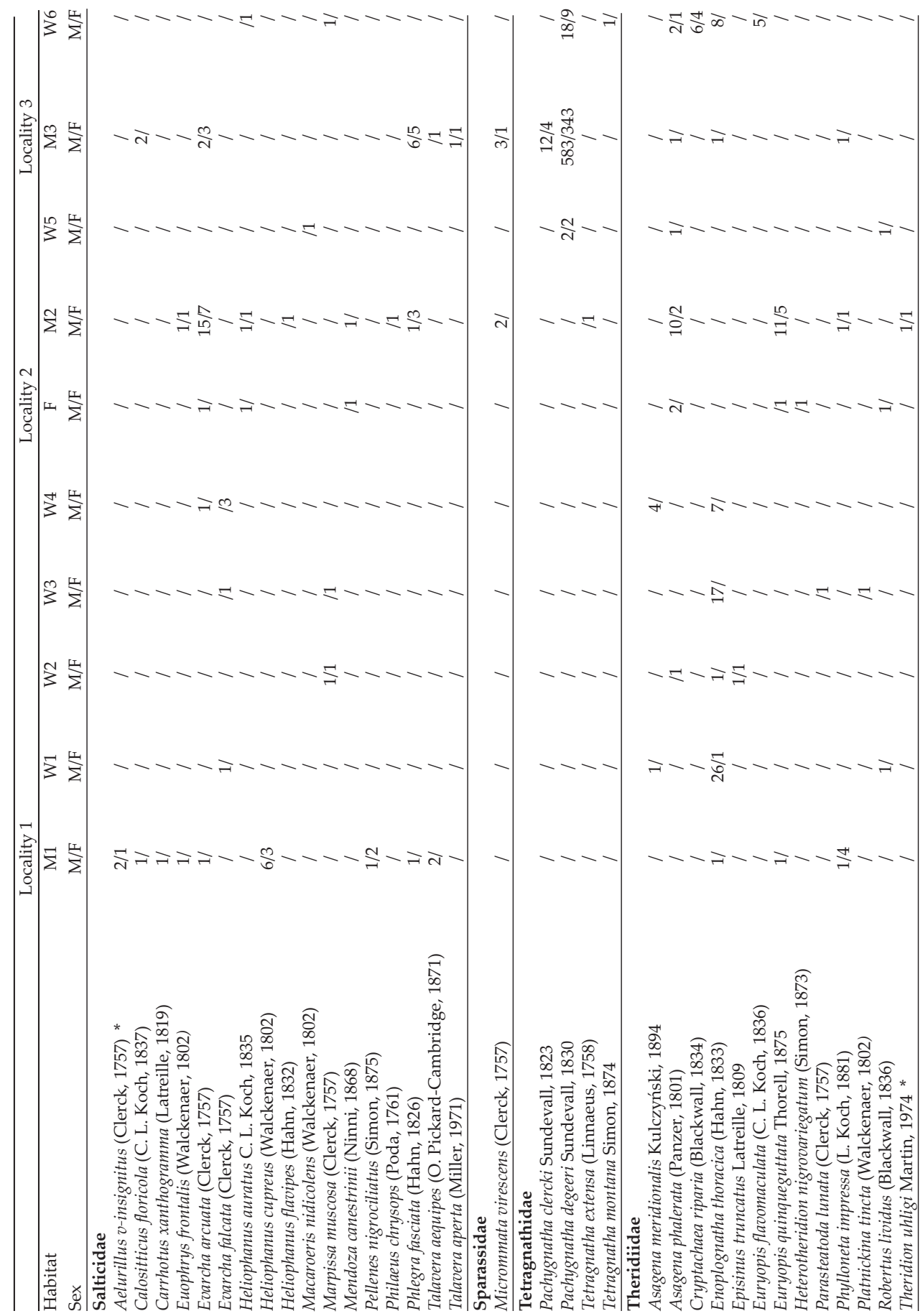




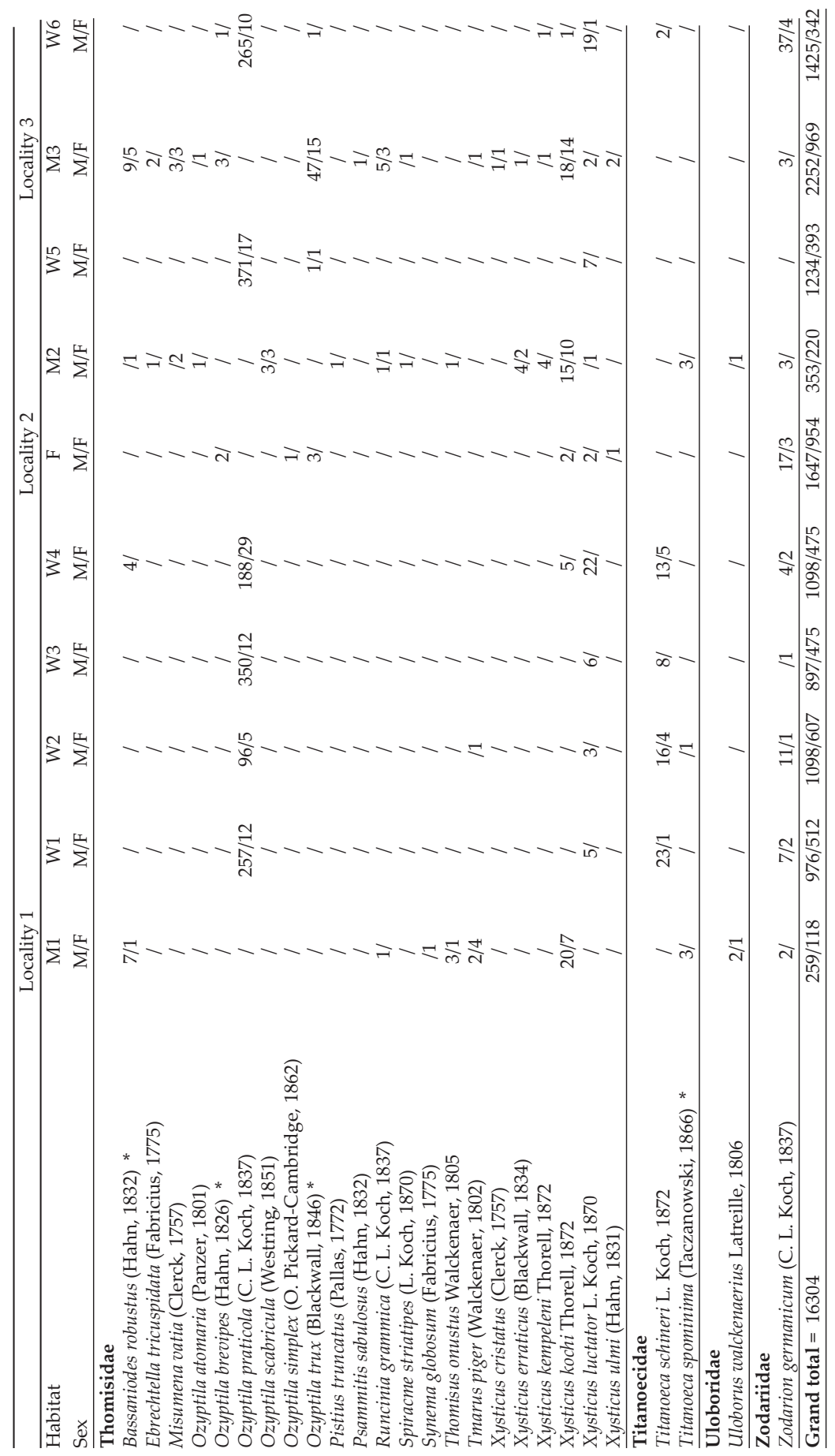


